\title{
Rheomorphic ignimbrites of the Rogerson Formation, central Snake River plain, USA: record of mid-Miocene rhyolitic explosive eruptions and associated crustal subsidence along the Yellowstone hotspot track
}

\author{
Thomas R. Knott ${ }^{1}$ - Marc K. Reichow ${ }^{1}$ - Michael J. Branney ${ }^{1}$ David R. Finn ${ }^{2}$. \\ Robert S. Coe ${ }^{2} \cdot$ Michael Storey $^{3} \cdot$ Bill Bonnichsen $^{4}$
}

Received: 24 July 2015 / Accepted: 27 January 2016 /Published online: 7 March 2016

(C) The Author(s) 2016. This article is published with open access at Springerlink.com

\begin{abstract}
Rogerson Graben, USA, is critically placed at the intersection between the Yellowstone hotspot track and the southern projection of the west Snake River rift. Eleven rhyolitic members of the re-defined, $\geq 420$-m-thick, Rogerson Formation record voluminous high-temperature explosive eruptions, emplacing extensive ashfall and rheomorphic ignimbrite sheets. Yet, each member has subtly distinct field, chemical and palaeomagnetic characteristics. New regional correlations reveal that the Brown's View ignimbrite covers $\geq 3300 \mathrm{~km}^{2}$, and the Wooden Shoe ignimbrite covers $\geq 4400 \mathrm{~km}^{2}$ and extends into Nevada. Between 11.9 and $\sim 8 \mathrm{Ma}$, the average frequency of large explosive eruptions in this region was 1 per $354 \mathrm{ky}$, about twice that at Yellowstone. The chemistry and mineralogy of the early rhyolites show increasing maturity with time possibly by progressive fractional crystallisation. This was followed by a trend towards less-evolved rhyolites that may record melting and
\end{abstract}

Editorial responsibility: R.J. Brown

Electronic supplementary material The online version of this article (doi:10.1007/s00445-016-1003-x) contains supplementary material, which is available to authorized users.

Thomas R. Knott

trk2@le.ac.uk

1 Department of Geology, University of Leicester, Leicester LE1 7RH, UK

2 Earth and Planetary Science Department, University of California, Santa Cruz, CA 95064, USA

3 Quaternary Dating Laboratory, Natural History Museum of Denmark, University of Copenhagen, Copenhagen, Denmark

4 Idaho Geological Survey, Moscow ID 83844, USA hybridisation of a mid-crustal source region. Contemporaneous magmatism-induced crustal subsidence of the central Snake River Basin is recorded by successive ignimbrites offlapping and thinning up the $\mathrm{N}$-facing limb of a regional basin-margin monocline, which developed between 10.59 and $8 \mathrm{Ma}$. The syn-volcanic basin topography contrasted significantly with the present-day elevated Yellowstone hotspot plateau. Concurrent basin-and-range extension produced the N-trending Rogerson Graben: early uplift of the Shoshone Hills ( $\geq 10.34 \mathrm{Ma}$ ) was followed by initiation of the Shoshone Fault and an E-sloping half-graben ( 10.3-10.1 Ma). The graben asymmetry then reversed with initiation of the Brown's Bench Fault ( $\geq 8 \mathrm{Ma}$ ), which remained intermittently active until the Pliocene.

Keywords Snake River Plain volcanic province $\cdot$ Yellowstone hotspot $\cdot$ Rheomorphic ignimbrite $\cdot$ Rhyolite $\cdot$ Volcanic stratigraphy $\cdot$ Basin and Range $\cdot$ Crustal flexure

\section{Introduction and geological setting}

The Yellowstone-Snake River Plain volcanic province (Fig. 1) is the youngest and best-preserved silicic intraplate volcanic province on Earth. It records large-scale (100's to 1000 's $\mathrm{km}^{3}$ ) explosive eruptions that were unusual both physically (i.e. very high-temperature, pumice-poor rhyolitic eruptions of 'Snake River type'; Branney et al. 2008) and chemically, constituting the largest volume of low- $\delta{ }^{18} \mathrm{O}$ volcanic rocks known on Earth (e.g. Boroughs et al. 2012; Colón et al. 2015). Interest centres upon how the magmas formed in such volume (Leeman et al. 2008; Shervais et al. 2013) and upon the unusual physical volcanology of the eruptions, their scale, frequency and environmental impact (Branney et al. 


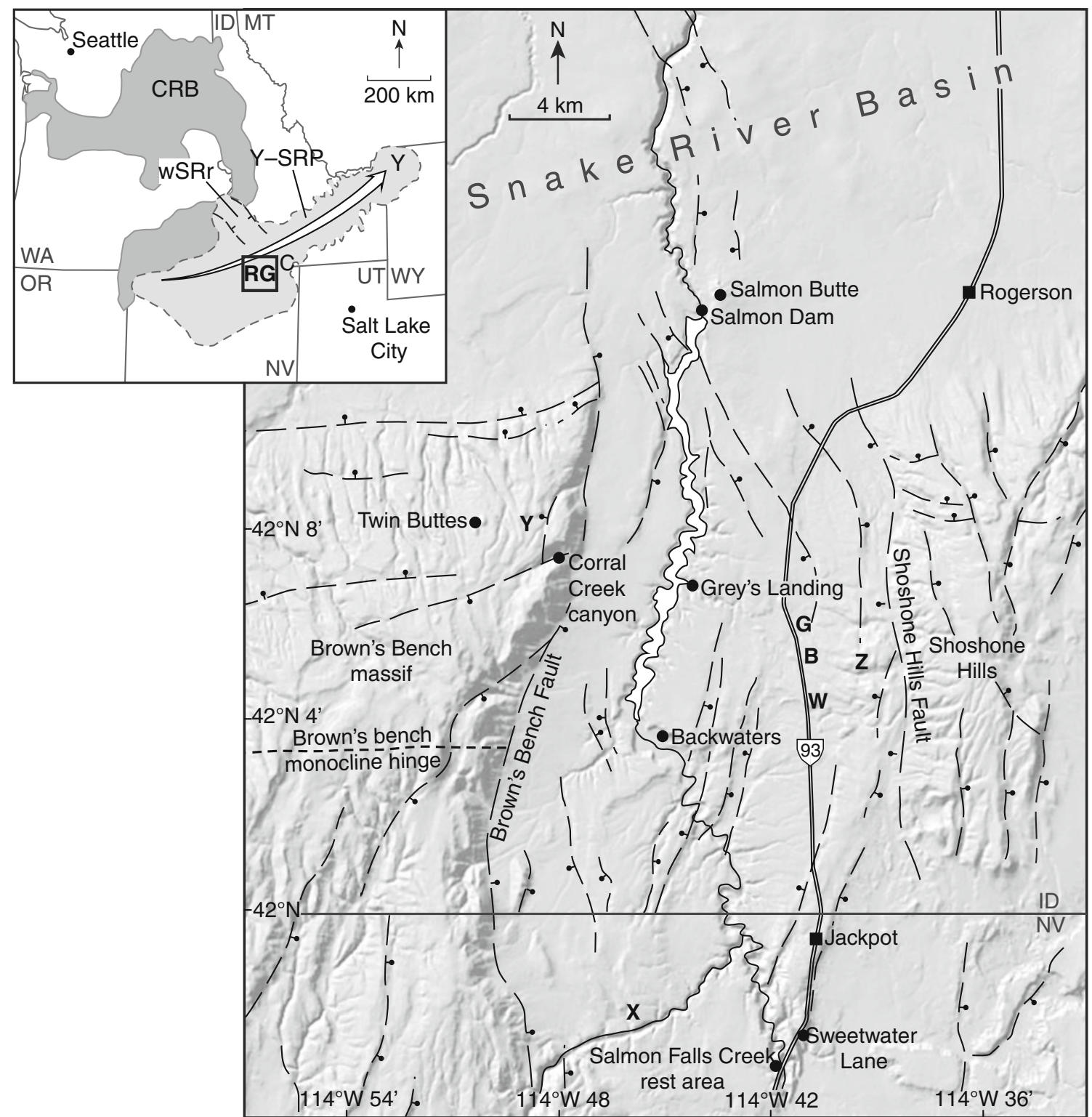

Fig. 1 Digital elevation map of the Rogerson Graben and surrounding areas. Key towns, and place names, along with major faults are indicated. Individual letters $(B, G$, and $W-Z)$ denote specific localities mentioned in the text. Inset map: Outline of the Yellowstone-Snake River Plain (Y-

2008; Self and Blake 2008; Ellis and Branney 2010). To properly understand these topics, it is essential to first develop a robust stratigraphic and temporal framework with sufficient resolution to distinguish the products of individual eruptions.

This paper documents the volcanic stratigraphy of a key part of the province in the central Snake River Plain where the hotspot track and the west Snake River rift intersect (Fig. 1) at the site of particularly intense magmatism (the ignimbrite 'flare-up' of Nash et al. 2006). The succession around Rogerson, Idaho, has been resolved and is now divided into 11 clearly defined eruption-units. The work builds upon recent studies further east, in the Cassia Hills (Knott et al. 2016), at Rogerson Graben (Andrews and Branney 2005; Andrews
SRP) volcanic province. Arrow indicates the broad NE-progression of volcanism. Location of the Rogerson Graben $(\mathrm{RG})$ is also indicated. Abbreviations: CRB Columbia River basalts, $Y$ Yellowstone, $w S R r$ west Snake River rift

et al. 2008), and to the west, at Brown's Bench escarpment (Bonnichsen et al. 2008; Fig. 1). In particular, we (1) present new definitions and correlations of eruption deposits supported by (2) new field, mineralogical and chemical data, (3) new high-resolution geochronology and (4) palaeomagnetic data. The new stratigraphic framework robustly defines individual eruption-units and thus provides significantly higher resolution than the broader 'composition and time (CAT) groups' of recent studies (Bonnichsen et al. 2008), and it reveals temporal trends in chemistry and mineralogy of Snake River Plain magmas during 11 large rhyolitic explosive eruptions between 11.9 and $\sim 8.0 \mathrm{Ma}$. We show that the eruptions occurred contemporaneously with continental extension (Basin-and-Range 
and opening of the western Snake River rift; Fig. 1) and we use new structural, kinematic and thickness-variation data to reconstruct the timing of major, magma-induced continental subsidence of the 100-km-wide Snake River Basin during this phase of intense magmatism. A complementary account of a rhyolitic volcanic succession further east, in the Cassia Hills, is given in Knott et al. (2016).

Following initial Columbia River flood basalt effusion (16.5 Ma; Coble and Mahood 2012), Snake River Plain rhyolitic volcanism gradually migrated from northern Nevada $\sim 600 \mathrm{~km}$ eastwards across southern Idaho to the present-day Yellowstone Volcanic Field (Fig. 1). The volcanism is commonly attributed to a mantle plume beneath the westmigrating North American plate (Armstrong et al. 1975; Cathey and Nash 2004; Pierce and Morgan 1992; Coble and Mahood 2012) although slab break-off (James et al. 2011) and regional extension in response to upper mantle convection (Christiansen et al. 2002) have also been invoked. More than $30,000 \mathrm{~km}^{3}$ of rhyolites are thought to have been generated due to melting by the incremental emplacement of an elongate ENE-trending, mid-crustal mafic sill at a depth of $\sim 12 \mathrm{~km}$ beneath the Snake River Basin (Rodgers et al. 2002; Leeman et al. 2008), which crosses numerous N and NWtrending extensional Basin-and-Range faults (Miller et al. 1999). The rhyolitic eruption centres are thought to lie concealed beneath younger basalt lavas in the Snake River Basin, and numerous extensive outflow ignimbrite sheets are exposed in massifs along the north and south flanks of the basin (Fig. 1). Associated fallout ashes are dispersed widely across continental USA (Perkins 1998).

\section{Methods and terminology}

Distinguishing the deposits of individual eruptions in the central Snake River Plain is challenging because the exposed successions of ignimbrites are thick, monotonous and intensely faulted: most units have similar rhyolitic chemistry and mineralogy and broadly similar field characteristics (intensely welded rheomorphic tuffs). Therefore, the best exposures were logged in detail ( $>30$ logs) at non-faulted reference sections and subdivided into individual eruption units (deposit packages inferred to record a single volcanic eruption) on the basis of intervening palaeosols, sedimentary horizons and contrasting palaeomagnetic directional signatures that indicate significant repose periods. Tops and bases of each unit were sampled for petrographic, geochemical, radiometric and palaeomagnetic analysis. Field mapping was undertaken locally to link key sections, determine faults, strata dips and lateral thickness variations.

$\mathrm{X}$-ray fluorescence (XRF) analyses were undertaken on fresh vitrophyres from which rare lithic fragments had been removed (sample locations and data given in Online Resource 2).
Crystals were characterised optically and by electron microprobe. XRF and electron microprobe analytic procedures, including standard data, are detailed in Knott et al. (2016). Separated sanidine feldspars were dated by ${ }^{40} \mathrm{Ar} /{ }^{39} \mathrm{Ar}$ methodology at the Quaternary Dating Laboratory (QUADLAB), Natural History Museum of Denmark. New age data are presented alongside published data (Table 1), and all data, including full age justifications, are given as supplementary files. Cores of vitrophyres and lithoidal parts of eruption units were drilled for palaeomagnetic analysis at the same key reference sections and processed at University of California, Santa Cruz, using methods described in Finn et al. (2015).

In this paper, we use 'eutaxitic' for welded tuff displaying sheared or flattened shards or fiamme. 'Lava-like' describes (without interpreting their origin) massive or flow-banded lithologies that lack such features and so resemble lava (Branney et al. 1992). 'Fused' ash is welded as the result of contact with a formerly hot adjacent rock (Fisher and Schmincke 1984). 'Intensely welded' tuff shows high strain and lacks remnant interstitial porosity (Smith 1960) and is 'rheomorphic' where there is evidence for ductile extension or folding prior to cooling (Branney et al. 2004). 'Vitrophyre' is chilled, mostly glassy welded tuff, whereas 'lithoidal' welded tuff is microcrystalline (including devitrified tuff). Devitrification features include spherulites ('axiolites' where planar) commonly within zones that span contacts between vitrophyres and lithoidal zones. Spherulites in the central Snake River area reach $35 \mathrm{~cm}$ in diameter and commonly have an irregular-shaped central cavity or 'lithophysae' (cf. Breitkreuz 2013). 'Sheet joints' are ramifying sub-horizontal joints orientated sub-parallel to bedding and spaced $~ 5-$ $30 \mathrm{~mm}$ apart (e.g. Bonnichsen and Citron 1982); because they are absent in vitrophyre, they likely form in response to stresses associated with slow cooling and devitrification. Although the ignimbrites in the central Snake River Plain are unusually intensely welded and develop flow-folding and upper flow breccias, they can readily be distinguished from true lavas by several features, key of which are (a) the widespread absence of basal autobreccias, which are ubiquitous in rhyolitic lavas (Bonnichsen and Kauffman 1987; Henry and Wolff 1992; Branney et al. 1992); and (b) the tendency of rheomorphic ignimbrites to thin gradually as they mantle topographic slopes, and as they approach their tapering distal terminations (e.g. Branney and Kokelaar 2002; Knott et al. 2016), in contrast to the more abrupt, lobate, steep and breccia-fringed terminations of true blocky lavas (Bonnichsen and Kauffman 1987).

\section{The Rogerson Formation}

Mid-Miocene rhyolitic ignimbrites of the Rogerson Formation are exposed around Rogerson Graben and 
Table 1 Summary of new and published radio-isotopic dates for members of the Rogerson Formation with sample locations, material type and method used. Note: All argon ages are relative to sanidine feldspar standard FCs at $28.172 \mathrm{Ma} \pm 0.028 \mathrm{Ma}$ (Rivera et al. 2011) and reported with $2 \sigma$ uncertainties

\begin{tabular}{llllll}
\hline Member & Sample number & Sample location & Sample type & Method & Weighted mean age (Ma) \\
\hline Grey's Landing & - & Rogerson Graben & - & Stratigraphic position & ${ }^{\mathrm{a}} \sim 8.0$ \\
Brown's View & - & Rogerson Graben & - & Constrained by underlying age & ${ }^{\mathrm{a}} \sim 10.0$ \\
& RC-11.1-004 & Cassia Hills & Zircon & Ionprobe (SIMS) & ${ }^{\mathrm{b}} 10.3 \pm 0.2$ \\
Twin Buttes & - & - & - & - & - \\
Wooden Shoe & RC-10.1-002 & Cassia Hills & Sanidine & Single-grain laser fusion & ${ }^{\mathrm{b}} 10.139 \pm 0.006$ \\
Bobcat Butte & - & Brown's Bench Escarpment & Sanidine & Single-grain laser fusion & ${ }^{\mathrm{d}} 10.34 \pm 0.09$ \\
Rabbit Springs & - & Brown's Bench Escarpment & Sanidine & Single-grain laser fusion & ${ }^{\mathrm{c}} 10.59 \pm 0.09$ \\
& - & Backwaters & Sanidine & Single-grain laser fusion & ${ }^{\mathrm{d}} 10.49 \pm 0.13$ \\
& - & Cottonwood Creek, Nevada & Sanidine & Single-grain laser fusion & ${ }^{\mathrm{c}} 10.62 \pm 0.10$ \\
Jackpot & RC-10.1-010 & Corral Creek & Sanidine & Single-grain laser fusion & ${ }^{\mathrm{a}} 10.960 \pm 0.009$ \\
& - & Brown's Bench Escarpment & Sanidine & Single-grain laser fusion & ${ }^{\mathrm{a}} 11.04 \pm 0.07$ \\
& - & Cassia Hills & Sanidine & Single-grain laser fusion & ${ }^{\mathrm{c}} 10.97 \pm 0.07$ \\
China Hill & - & Brown's Bench Escarpment & - & Stratigraphic position & ${ }^{\mathrm{a}} \sim 11.3 \mathrm{Ma}$ \\
Black Canyon & RC-10.1-002 & Corral Creek & Sanidine & Single-grain laser fusion & ${ }^{\mathrm{a}} 11.667 \pm 0.017$ \\
& & Brown's Bench Escarpment & Sanidine & Single-grain laser fusion & ${ }^{\mathrm{c}} 11.40 \pm 0.08$ \\
Brown's Bench & RC-10.1-002 & Corral Creek & Sanidine & Single-grain laser fusion & ${ }^{\mathrm{a}} 11.857 \pm 0.006$ \\
Corral Creek & MP-11.2-001 & Corral Creek & Sanidine & Single-grain laser fusion & ${ }^{\mathrm{a}} 11.938 \pm 0.004$ \\
\hline
\end{tabular}

${ }^{\mathrm{a}}$ This study (see Online Resource 4-Table S4)

${ }^{\mathrm{b}}$ Knott et al. 2016

${ }^{\mathrm{c}}$ Ellis et al. 2012

${ }^{\mathrm{d}}$ Bonnichsen et al. 2008

Brown's Bench escarpment, Idaho (Fig. 1) and belong to the Idavada Volcanic Group (Malde and Powers 1962; Andrews et al. 2008). The formation exceeds $420 \mathrm{~m}$ thickness (base not seen; Fig. 2) and comprises rhyolitic ignimbrites and thinner ashfall layers thought to be derived from eruptive sources concealed beneath basalts in the central Snake River Plain (Bonnichsen et al. 2008). Prior to this study, it was subdivided into five members (Andrews and Branney 2005; Andrews et al. 2008), with another 12 informal units ('BBU 1-12' of Bonnichsen et al. 2008) reported on the adjacent Brown's Bench scarp (Fig. 1) of which two were correlated with units in the graben (Ellis et al. 2012).

The present study combines new data into a significantly revised formation of 11 members (Fig. 2) defined at three linked reference sections around Rogerson: Corral Creek on Brown's Bench scarp, Backwaters in Rogerson Graben and Salmon Falls Creek south of Jackpot, Nevada (Fig. 1). First, we define, characterise and interpret each member below (type section coordinates given in Online Resource 1) using new field, geochemical, palaeomagnetic and high-precision radiometric data. We then reconstruct the volcanic, magmatic and tectonic history of mid-Miocene southern central Idaho, at a time of particularly active volcanism and tectonism. The new type locations and robust definitions should eliminate ambiguity and benefit future stratigraphic, volcanological, petrogenetic and tectonic studies in the region. A brief summary of the characteristics of each member can be found in Online Resource 1.

\section{Corral Creek Member}

The Corral Creek Member (Fig. 2; 'BBU-2' of Bonnichsen et al. 2008) is a crystal-poor $(<2 \%)$ intensely welded and rheomorphic rhyolitic ignimbrite, $>20 \mathrm{~m}$ thick, exposed near the base of the Corral Creek section (Fig. 1). It is massive to flow-laminated, lava-like and lithic-poor, with ubiquitous metre-scale rheomorphic folds and platy joints. Only the central lithoidal part is exposed. It is the oldest member exposed in Corral Creek, although a rather poorly exposed silicified rhyolite of unknown origin occurs $\sim 2 \mathrm{~km}$ further south ('BBU-1' of Bonnichsen et al. 2008). The Corral Creek Member has a reversed magnetic polarity (Fig. 3a), and we present a high-precision ${ }^{40} \mathrm{Ar} /{ }^{39} \mathrm{Ar}$ age of $11.938 \pm 0.004 \mathrm{Ma}$ (Table 1). Its mineralogy is typical of Snake River-type rhyolites of Idaho, with sanidine, plagioclase, pigeonite, augite, magnetite, ilmenite and accessory zircon and apatite. However, it has several distinctive characteristics: (1) conspicuously larger $(\sim 2 \mathrm{~mm})$ sanidine crystals than in all overlying 


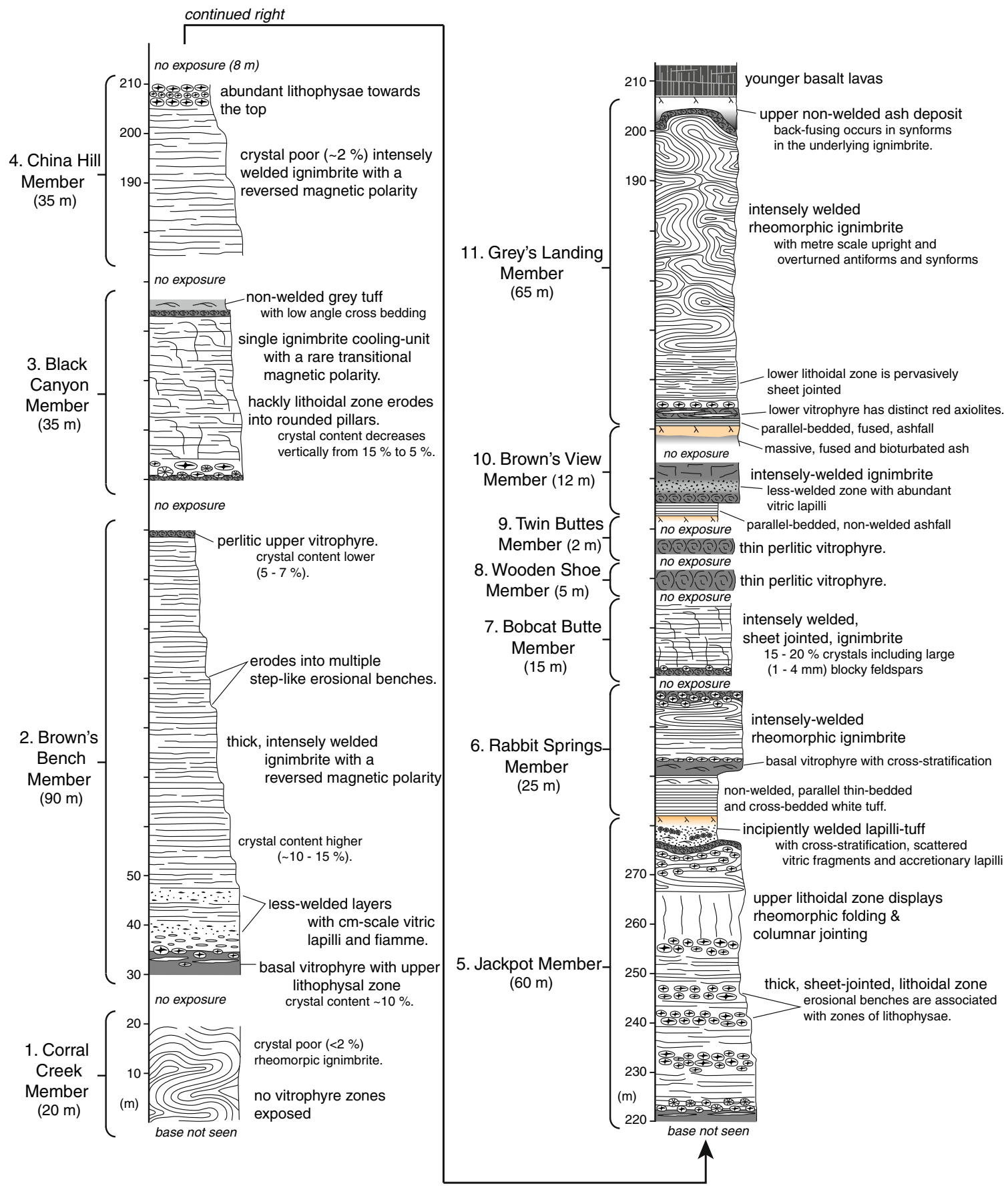

Key (symbols not to

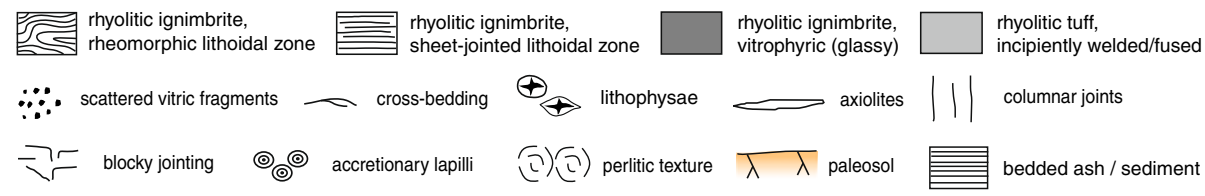

basalt lava

Fig. 2 Generalised vertical section of the Rogerson Formation showing the physical features of eleven members (1-11), each inferred to be a major rhyolitic eruption-unit 
(a)

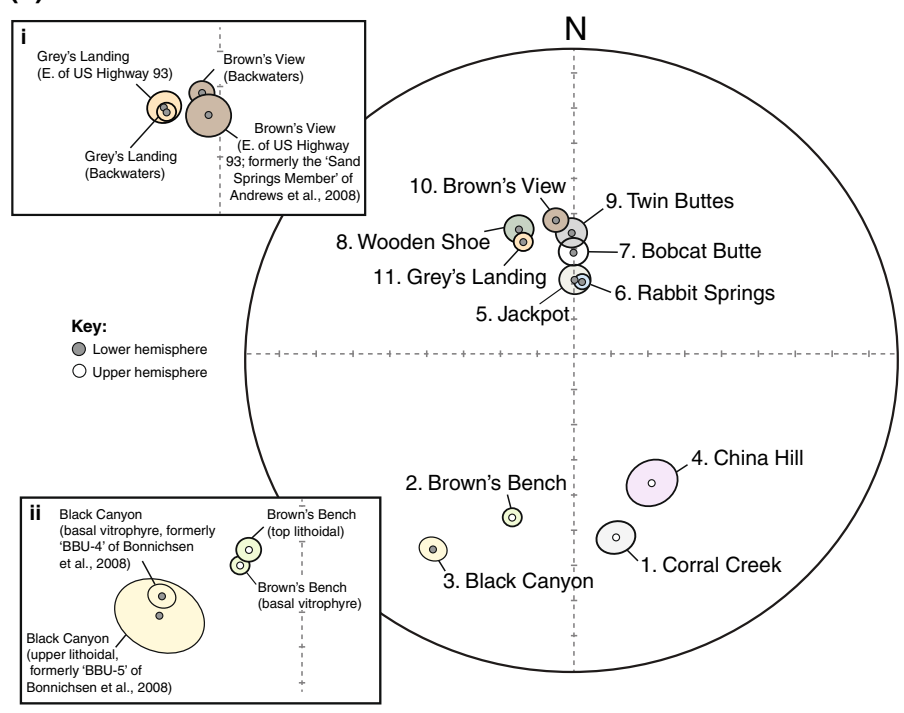

Fig. 3 a Stereographic plot of mean thermoremanent magnetic (TRM) directions ( $>10$ cores per member) for all Rogerson Formation members. The oldest members typically exhibit reversed magnetic polarity, except for the Black Canyon Member which has a rare transitional polarity, whereas younger members exhibit normal polarity. (Inset $i$ ) Individual site mean TRM directions for the Grey's Landing and Brown's View members at Backwaters and east of US Highway 93. The indistinguishable directions of each member at each locality support the E-W

members, (2) sanidine predominates over plagioclase, and (3) quartz-sanidine micrographic (granophyric) intergrowths are abundant. Chemically, the ignimbrite is a high-silica rhyolite (75 wt. $\% \mathrm{SiO}_{2}$ ) and can be distinguished from other members by its low $\mathrm{MgO}(<0.07$ wt.\%) and high $\mathrm{Ba}$ contents $(1000 \mathrm{ppm})$. No vertical variations are exhibited.

\section{Interpretation}

The homogeneous, massive, intensely welded nature of this ignimbrite, and the absence of internal vitrophyres, welding variations or other breaks within the main lithoidal zone, is consistent with the member representing a non-zoned, simple cooling unit of outflow ignimbrite, deposited by a very hot, granular fluid-based pyroclastic density current (Branney and Kokelaar 2002) .

\section{Brown's Bench Member}

The Brown's Bench Member is the thickest ( $90 \mathrm{~m}$ ) and most complex ignimbrite on Brown's Bench scarp. At the type area (Coral Creek Canyon; Fig. 1), it overlies the Corral Creek Member and underlies the Black Canyon Member (contacts not seen; Fig. 2). It has a reversed magnetic polarity (Fig. 3a), and its thermoremanent magnetisation (TRM) direction is distinct from the enclosing members (Fig. 3a). We also present a high-precision ${ }^{40} \mathrm{Ar} /{ }^{39} \mathrm{Ar}$ age for this member of 11.857 (b)

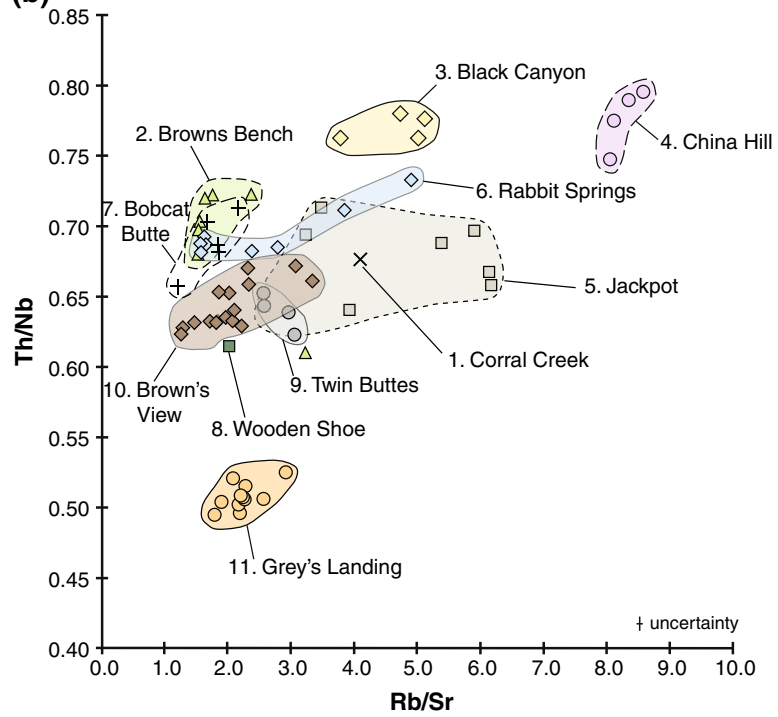

stratigraphic revisions to that proposed by Andrews et al. (2008). (Inset ii) Individual site mean TRM directions derived from the base and top of the Brown's Bench and Black Canyon members. b Members of the Rogerson Formation (1-11) occupy discrete chemical fields on a $\mathrm{Rb} / \mathrm{Sr}$ versus $\mathrm{Th} / \mathrm{Nb}$ plot (data from this study, see Online Resource 2). Where the fields overlap (e.g. 2 and 7), they are readily distinguished by their contrasting stratigraphic position, field characteristics (Fig. 2) and palaeomagnetic signature (see left)

\pm 0.006 Ma (Table 1). The Brown's Bench Member (Fig. 4) comprises a basal massive vitrophyric tuff, $\sim 5 \mathrm{~m}$ thick, with an upper zone of sparse elongate lithophysal spherulites, $\sim 0.3 \mathrm{~m}$ in diameter, and metre-long axiolites. The vitrophyre is sharply overlain by a red-brown, lava-like lithoidal zone, $70 \mathrm{~m}$ thick, which forms 10 conspicuous step-like erosional benches along Brown's Bench scarp (Fig. 4c). Two lessintensely welded zones with gradational contacts, 5 and $10 \mathrm{~m}$ above the base of the lithoidal zone (Fig. 4a), contain fiamme and abundant blocky, non-vesicular vitric lapilli (Fig. 4b). The overlying lithoidal tuff is rheomorphic and is overlain by a $\geq 1$-m-thick upper perlitic vitrophyre, although the upper $10 \mathrm{~m}$ are commonly obscured. Crystal content varies with height through the Brown's Bench Member, from 10\% in the basal vitrophyre to $10-15 \%$ in the lithoidal zone and 5$7 \%$ in the upper vitrophyre. The member is mineralogically distinct from the overlying Black Canyon Member in that it contains an additional compositional mode of pigeonite together with a compositional pair of pigeonite and augite (Fig. 5). It can also be distinguished from enclosing members by its combination of lower $\mathrm{SiO}_{2}(\leq 73.38 \mathrm{wt} . \%)$ and relatively higher $\mathrm{TiO}_{2}$ (>0.5 wt.\%), $\mathrm{MgO}$ (>0.2 wt.\%), $\mathrm{Fe}_{2} \mathrm{O}_{3}$ (>3.6 wt.\%) and $\mathrm{Zr}$ (>550 ppm) (Online Resource 2).

\section{Interpretation}

The Brown's Bench Member is a thick outflow ignimbrite that originated from a source somewhere in the central Snake 


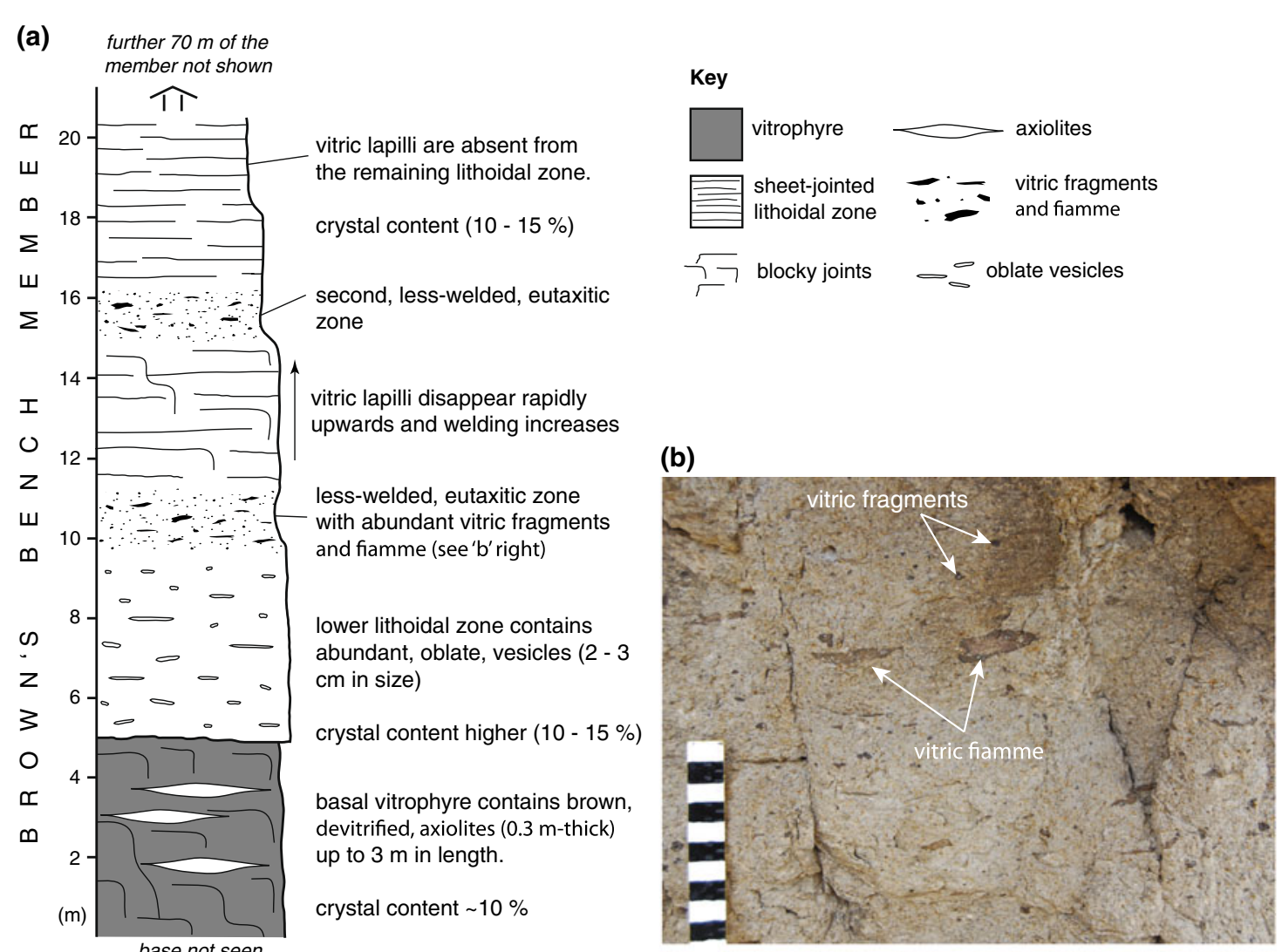

(c)

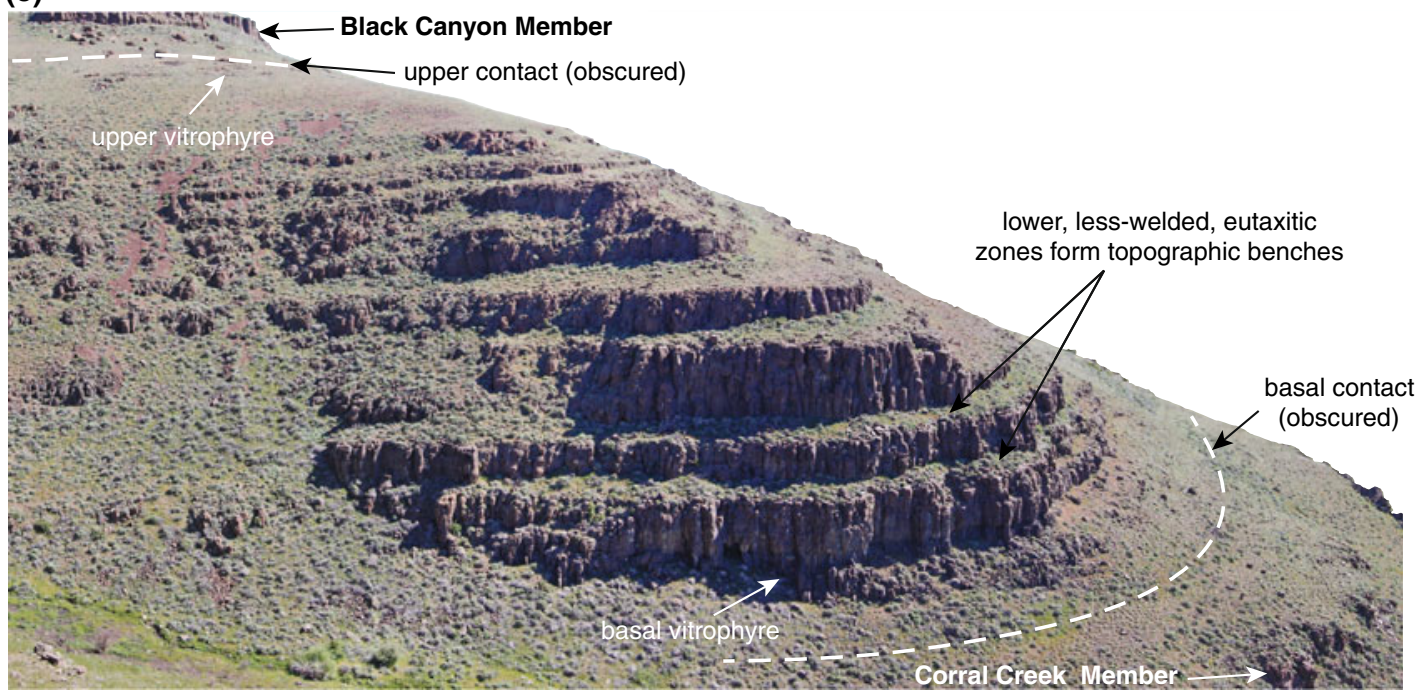

Fig. 4 a Graphic log of the lower $20 \mathrm{~m}$ of the Brown's Bench Member showing the unusual less-welded, eutaxitic zones containing abundant vitric fragments and fiamme (detailed photograph ' $b$ '). c Overview of

River Basin. Its uniform palaeomagnetic direction (Fig. 3a, inset ii), together with an absence of internal breaks, palaeosols or reworked horizons, show that it is a single eruption unit. The complex welding profile in lower parts (Fig. 4a) is similar to a compound cooling unit that would classically be interpreted as recording at least three separate pyroclastic the entire Brown's Bench Member. Note how the member forms several, prominent topographic benches

density currents in rapid succession (two short-duration currents followed by a more protracted one), with intervening periods during which deposit tops cooled. However, we note that the two less-welded, eutaxitic zones that alternate with the intensely welded zones coincide with abundant blocky vitric lapilli. Therefore, we infer the passage of a prolonged density 
current, during which two abrupt influxes of the blocky vitric fragments occurred during the first half of the eruption. The two influxes of vitric fragments in such large quantity (traced for more than $55 \mathrm{~km}$ from the inferred source area) indicate major fragmentation events with entrainment of an abundant proximal glassy source. These significant events may have involved hydroclastic explosive fragmentation (e.g. Ellis and Branney 2010) or caldera collapse-triggered proximal avalanching of earlier-formed glassy rhyolite deposits in the source area, with consequent entrainment of the glassy debris into the pyroclastic density current. Similar occurrences of abundant blocky vitric lapilli at horizons within thick massive ignimbrites have been described in Snake River-type ignimbrites elsewhere (e.g. Big Bluff Member, Knott et al. 2016).

\section{Black Canyon Member}

The Black Canyon Member is a 35-m-thick intensely welded rhyolitic ignimbrite sheet with a new high-precision ${ }^{40} \mathrm{Ar} /{ }^{39} \mathrm{Ar}$ age of $11.667 \pm 0.017 \mathrm{Ma}$ (Table 1). At the type area, Corral Creek Canyon, it overlies the Brown's Bench Member and is overlain by the China Hill Member (Fig. 2). It is eroded into a double bench and had previously been interpreted as two separate units ('BBU-4' and 'BBU-5'; Bonnichsen et al. 2008) on the basis that field flux-gate magnetometer readings indicated normal polarity for the lower bench and reversed polarity for the upper bench. There is, however, no internal vitrophyre, palaeosol, fallout or sedimentary horizon to support a significant repose period, and new palaeomagnetic data derived from 23 oriented cores reveal that both benches share the same magnetic polarity and direction (Fig. 3a, inset ii). This is a rare transitional polarity not seen in any other member, and it indicates that the entire Black Canyon Member is a single eruption unit.

A well-exposed 1-m-thick perlitic vitrophyre at the base of the member is sharply overlain by massive, brown lithoidal tuff (Fig. 2), the lower $\sim 2 \mathrm{~m}$ of which contains lithophysae, $\leq 40 \mathrm{~cm}$ in diameter. Above this, the tuff is pervasively sheetjointed and characteristically weathers to form prominent rounded erosional pillars. An upper perlitic vitrophyre, $1 \mathrm{~m}$ thick, contains small $(1-4 \mathrm{~cm})$ lithophysae and is overlain by $3 \mathrm{~m}$ of non-welded grey tuff that locally displays low-angle cross-stratification. The base of the grey tuff is darker, possibly due to fusing caused by deposition onto the still hot underlying welded ignimbrite.

The Black Canyon Member is vertically zoned with respect to phenocryst abundance, which decreases with height from $15 \%$ near the base to $\sim 5 \%$ in the upper vitrophyre. The member also can be distinguished from the underlying Brown's Bench Member by its higher $\mathrm{SiO}_{2}(\sim 74$ wt.\%) and

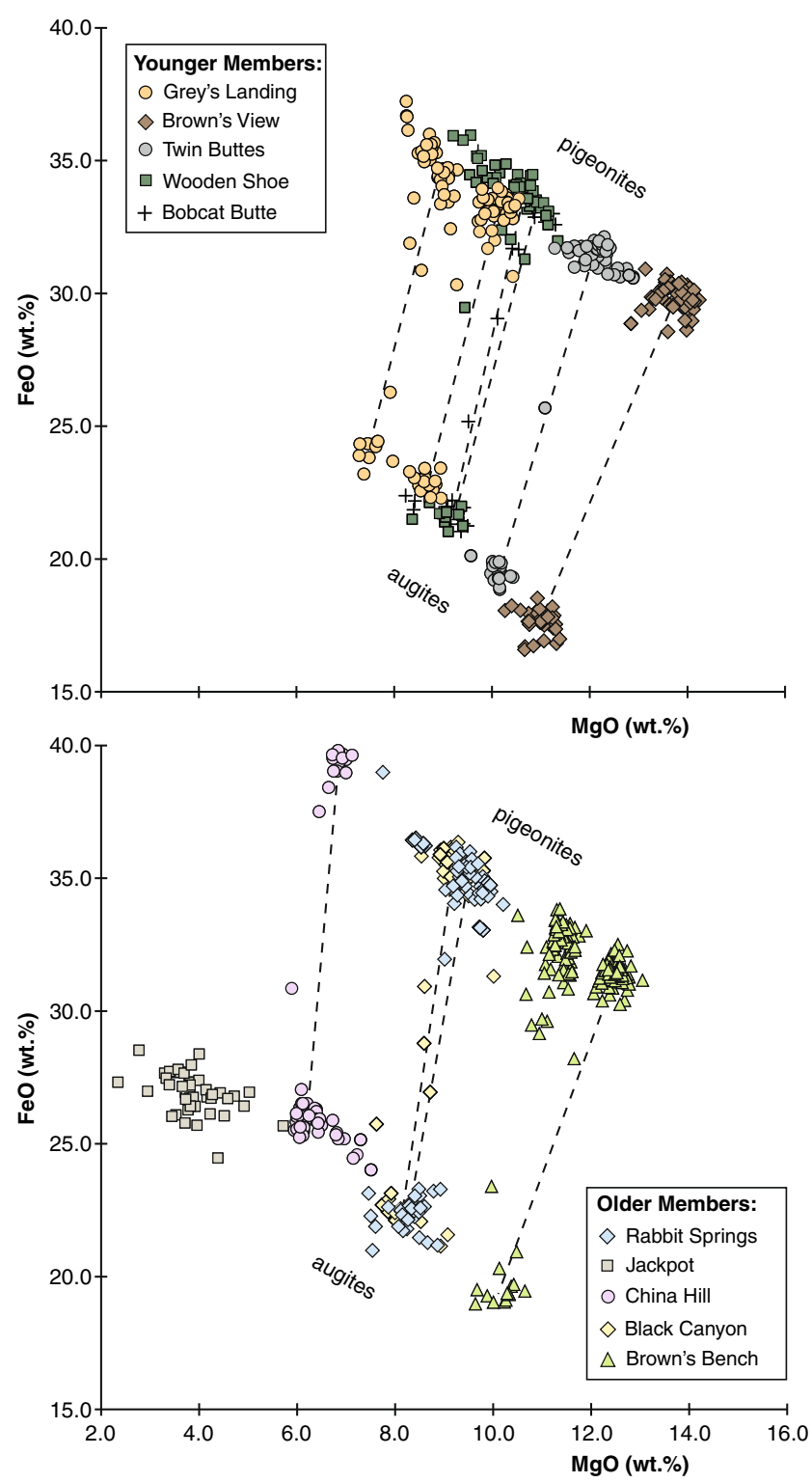

Fig. $5 \mathrm{FeO}$ versus $\mathrm{MgO}$ in pyroxene demonstrating compositional modes present in each member of the Rogerson Formation. Note that the Brown's Bench and Grey's Landing members contain multiple compositional modes of pyroxenes. Dashed lines denote equilibrium pairs (established using 'QUILF' after Andersen et al. 1993)

$\mathrm{Rb}$ (219-227 ppm) content and from the overlying China Hill Member, which has higher $\mathrm{SiO}_{2}(\sim 76$ wt.\%) and lower $\mathrm{Ba}$ concentrations (609-709 ppm) (Online Resource 2). The upper part of the Black Canyon Member has been correlated with Cougar Point Tuff XI of Bonnichsen and Citron (1982) further west (Ellis et al. 2012).

\section{Interpretation}

The ignimbrite is a simple cooling unit (c.f. Smith 1960), and its thick, massive nature with subtle zoning is interpreted to record a prolonged, granular fluid-based pyroclastic density 
current, fed by an eruption in which the proportion of crystals decreased gradually with time. Towards the end of the eruption, the current became fully dilute, with fluid turbulence in lower parts of the current favouring tractional segregation and development of the cross-stratification (e.g. Brown and Branney 2013). As would be expected, the increased airingestion in the late waning phase of the current also resulted in cooling, as recorded by the non-welded zone at the top.

\section{China Hill Member}

The China Hill Member ('BBU-6' of Bonnichsen et al. 2008), $35 \mathrm{~m}$ thick, is a crystal-poor $(\sim 2 \%)$ rheomorphic ignimbrite that, at the Corral Creek type section, overlies the Black Canyon Member and underlies the Jackpot Member (Fig. 2). It forms three widely traceable benches $\sim 2 \mathrm{~m}$ high, separated by 1 and 2 -m-high non-exposed slopes. The member is intensely welded, red-brown lithoidal tuff with sub-horizontal and hackly fractures. Basal and upper vitrophyres are not exposed. The upper $3 \mathrm{~m}$ characteristically displays a lithophysal zone in which a band of smaller $(\sim 1 \mathrm{~cm})$ lithophysae is sandwiched between two bands of larger $(\sim 3 \mathrm{~cm})$ lithophysae. Above this, an unexposed 8-m-high slope probably conceals an upper vitrophyre and overlying volcaniclastic sediments (Bonnichsen et al. 2008).

The China Hill Member has the highest $\mathrm{Rb} / \mathrm{Sr}$ ratio ( 8.4) and lowest Ba content (609-709 ppm) of all the members of the Rogerson Formation (Online Resource 2), and it also can be distinguished from its enclosing members as it has a reversed magnetic polarity and different TRM direction (Fig. 3a).

\section{Interpretation}

The member is inferred to record the passage of a hot granular fluid-based pyroclastic density current rather similar to the one that deposited the underlying Black Canyon ignimbrite. The three benches likely record some thermal or flow unsteadiness but would require more complete exposure to interpret.

\section{Jackpot Member}

The Jackpot Member (Andrews et al. 2008 and 'BBU-7' of Bonnichsen et al. 2008) is a complex, 60-m-thick rheomorphic rhyolitic ignimbrite. At Corral Creek, it overlies the China Hill Member and is overlain by the Rabbit Springs Member. The internal features are best exposed at the Salmon Falls Creek rest area south of Jackpot township (Nevada; Fig. 1) after which it is named. We present a high-precision ${ }^{40} \mathrm{Ar} /{ }^{39} \mathrm{Ar}$ age of $10.960 \pm 0.009 \mathrm{Ma}$ (Table 1).
The Jackpot Member is the oldest ignimbrite in the Rogerson Formation to have normal magnetic polarity (Fig. 3a) and can also be distinguished by the presence of abundant quartz crystals, fayalitic olivine and a distinctive composition of augite, whereas all other members of the formation contain both augite and pigeonite. Crystal abundance increases with height from 3-7\% to $10-15 \%$, as with the overlying Rabbit Springs Member. The whole-rock chemistry is broadly similar to other members (Online Resource 2).

Massive, lithoidal and rheomorphic lava-like tuff, $50 \mathrm{~m}$ thick, has eroded into five cliffs, 5-20 m high ('Jackpot 1-5' on Fig. 6a) separated by benches that each correspond to a lithophysal zone. Along US Highway 93 at Sweetwater Lane (Fig. 1), a discontinuous upper vitrophyre, $2 \mathrm{~m}$ thick, overlies massive lithoidal lava-like tuff with sparse cognate crystalrich, vesicular enclaves (Fig. 6d). Lithophysae filled with lime-green chalcedony span the contact with the platy jointed upper part of the lithoidal zone. Sharply overlying the vitrophyre is a mostly massive, 2-3-m-thick pink lapilli-tuff ('Jackpot 6', Fig. 6b) with abundant blocky vitric fragments ( $2-10 \mathrm{~mm}$ in size) but no pumice. An impersistent layer of low-angle cross-bedded tuff contains 1-cm-diameter accretionary lapilli (Fig. 6c), some cored by a non-vesicular vitric fragment (Fig. 8a of Branney et al. 2008). The lowest $20 \mathrm{~cm}$ of the pink lapilli-tuff seems to have been fused by deposition onto hot vitrophyre. The top of the Jackpot Member is marked by a palaeosol (e.g. at Backwaters, Fig. 1) and is sharply overlain by the Rabbit Springs Member. An overlying unit along Cottonwood Creek, Nevada (X on Fig. 1) was thought to be part of the Jackpot Member ('Jackpot 7' of Andrews et al. 2008; Ellis et al. 2012) but is now recognised to be the Rabbit Springs Member (see below). The Jackpot Member has been widely correlated across the southern Snake River Plain ('Cougar Point Tuff XIII' 1000 km³ ; Ellis et al. 2012) and is described, with several of its distinctive internal features in the Cassia Hills, further east (Knott et al. 2016, where it is locally known as the 'Big Bluff Member').

\section{Interpretation}

The volume of the Jackpot Member is consistent with deposition from a caldera-forming super eruption. The member is a compound cooling unit, outflow ignimbrite (Smith 1960; Wilson and Hildreth 2003). Its massive nature indicates deposition from predominantly granular fluid-based pyroclastic density currents (Branney and Kokelaar 2002). Since lithophysal zones in ignimbrites typically mark transitions between lithoidal and chilled vitrophyres (e.g. Bonnichsen and Citron 1982; Breitkreuz 2013), the four internal lithophysal zones (Fig. 6a) may record four brief chilling events of insufficient duration to preserve vitrophyre. No internal fallout, palaeosol or sediment layers have been seen within the member that would indicate a protracted repose period, and the 
fusing at the base of 'Jackpot 6' indicates emplacement prior to cooling of 'Jackpot 5'. However, 'Jackpot 1' and 'Jackpot 5 ' have differing mean TRM directions (angular separation of $14^{\circ}$, Fig. 6e) indicating a potential time gap of decades. The last phase of the eruption was marked by an abrupt influx of angular vitric fragments associated with lower-temperature pyroclastic density currents (the upper pink lapilli-tuff; 'Jackpot 6'). This change may reflect similar fragmentation events as those that occurred during the older Brown's Bench eruption. Fully dilute, turbulent currents flowed $>60 \mathrm{~km}$ from source, as recorded by the tractional cross-stratified facies within the pink lapilli-tuff. High moisture levels within a lofted ash plume rained ash pellets and vitric fragments into the turbulent, fully dilute pyroclastic current, wherein successive fine ash rims accreted around a central pellet or vitric fragment, forming the abundant large accretionary lapilli (see Brown et al. 2010). After deposition of the pink lapillituff, the hot ignimbrite beneath continued to deform rheomorphically, folding the lapilli-tuff in syncline cores prior to its lithification. The cooling zonation and vertical and lateral variations within this complex ignimbrite would reward further study.

\section{Rabbit Springs Member}

The Rabbit Springs Member (Andrews et al. 2008) is $20 \mathrm{~m}$ thick and rhyolitic, with an ashfall deposit overlain by an intensely welded, locally rheomorphic ignimbrite (Fig. 2). It is defined at its type area at Backwaters (Fig. 1) where it has normal magnetic polarisation (Fig. 3a), overlies an orange palaeosol at the top of the Jackpot Member and is overlain by the Brown's View Member. The Rabbit Springs Member is the oldest member to be widely exposed across the Rogerson Graben (Fig. 7). It is well-exposed along Cottonwood Creek (X on Fig. 1), and it forms the uppermost crag at Corral Creek Canyon (formerly 'BBU-8'; Bonnichsen et al. 2008) and is locally overlain by the Bobcat Butte Member. The Rabbit Springs Member, along with all overlying members, also exhibits intriguing thickness variations from west to east across the Rogerson Graben (Fig. 7). The cause of these variations is likely related to the tectonic development of the Rogerson Graben (see below).

The Rabbit Springs Member was once thought to be distinct from a local unit referred to as 'Jackpot 7' of Andrews et al. (2008). However, the two units are never seen together in stratigraphic continuity. New palaeomagnetic (Fig. 3a), whole-rock (Fig. 3b) and mineral (Fig. 5) data along with new and published radio-isotopic dates (Table. 1) show these units to be indistinguishable, and they are now considered to be the same.

At the Backwaters type section, an 8-m-thick layer of nonwelded parallel-bedded white ash is overlain by a 12-m-thick intensely welded ignimbrite. The lower metre of the ignimbrite is incipiently welded lapilli-tuff with low-angle crossbedding, sparse accretionary lapilli and angular vitric lapilli (Fig. 7). Welding increases rapidly upwards into a 3-m-thick perlitic vitrophyre, and the low-angle cross-bedding is highlighted by crystal-rich lenses (Fig. 8a). Smaller ( $\leq 5 \mathrm{~mm}$ ) vitric fragments continue up into the vitrophyre and are best seen in thin section (Fig. 8b). A prominent zone of 10 30-cm-diameter lithophysal spherulites occurs within the top of the vitrophyre and is sharply overlain by lithoidal tuff, $4 \mathrm{~m}$ thick. A second, upper zone of abundant spherulites and lithophysae $(3-5 \mathrm{~cm}$ in size) spans the contact with the 2-m-thick, upper vitrophyre (Fig. 7). Crystal content increases with height from $3 \%$ in the lower vitrophyre to $10-15 \%$ in the lithoidal zone and upper vitrophyre.

The ignimbrite thickens westwards to $30 \mathrm{~m}$ at Brown's Bench escarpment, where the top develops rheomorphic folds (e.g. at Corral Creek Canyon, Fig. 7). It also thins eastward beyond US Highway 93 ( $\mathrm{Z}$ on Fig. 1), where the central lithoidal zone pinches out and the entire ignimbrite thickness is non-rheomorphic vitrophyre (Fig. 7).

\section{Interpretation}

The Rabbit Springs Member is both a single eruption unit and a simple cooling unit. The eruption was zoned with respect to crystal content and began with a protracted phase of unsteady ashfall followed by a sustained pyroclastic density current. The current was initially relatively cool and fully dilute (recorded by the incipiently welded lower part with tractional lowangle cross-stratification) and later became hotter, more crystal-rich and granular fluid-based as recorded by the intensely welded, massive tuff. The westward thickening may reflect lower elevation in the west at the time of the eruption.

\section{Bobcat Butte Member}

The Bobcat Butte Member is a relatively crystal-rich (15$20 \%$ ) intensely welded ignimbrite that forms a $15 \mathrm{~m}$ cliff $\sim 0.2 \mathrm{~km}$ west of the crest of Brown's Bench escarpment (Corral Creek Canyon type locality; Fig. 1). It overlies the Rabbit Springs Member and is overlain by the Twin Buttes Member (Fig. 2) and is absent in central and eastern parts of Rogerson Graben (Fig. 7). It has an ${ }^{40} \mathrm{Ar} /{ }^{39} \mathrm{Ar}$ age of 10.34 $\pm 0.09 \mathrm{Ma}$ (Bonnichsen et al. 2008), has normal magnetic polarisation (Fig. 3) and can be distinguished from other units nearby by the presence of large $(\leq 4 \mathrm{~mm})$, blocky feldspar crystals. It is also the youngest member on Brown's Bench escarpment to contain sanidine. 

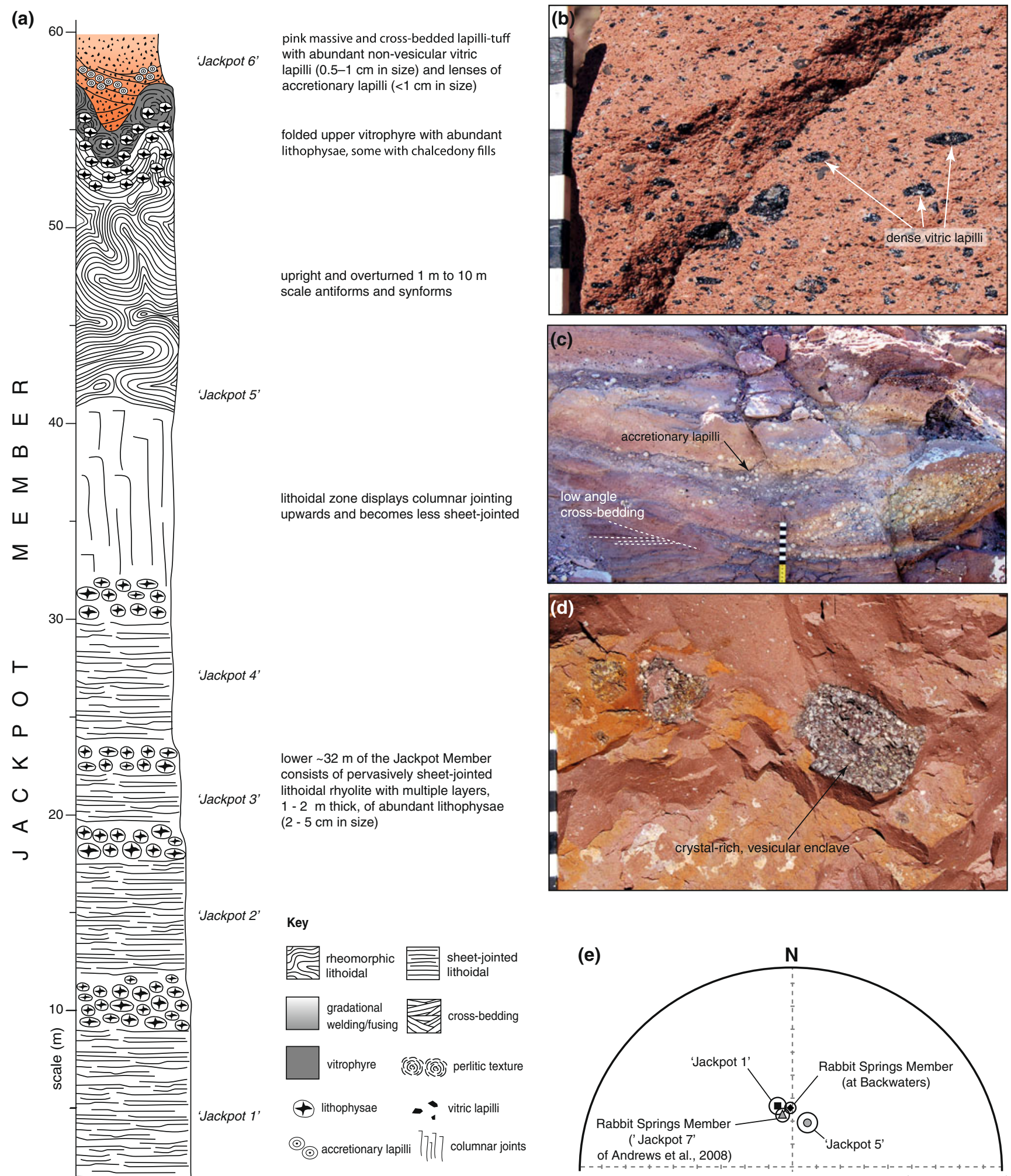

(all lower hemisphere)

base not seen

Fig. 6 a Detailed log of the Jackpot Member showing all physical features and informal sub-divisions ('Jackpot 1-6' of Andrews et al. 2008). b Upper massive lapilli-tuff ('Jackpot 6') containing abundant dense, non-vesicular vitric lapilli. $\mathbf{c}$ Low-angle cross-bedding and lenses of $\mathrm{cm}$-scale accretionary lapilli in the lower part of 'Jackpot 6'. d Crystal-rich vesicular enclaves in the

massive lithoidal zone of 'Jackpot 5' at Sweetwater Lane (Fig. 1). e Mean TRM directions of 'Jackpot 1' and 'Jackpot 5' are different, suggesting a possible brief repose period. Note the indistinguishable mean TRM directions of Jackpot 1, 'Jackpot 7' (of Andrews et al. 2008) and the Rabbit Springs members (this study). The latter two are now considered to be correlatives 


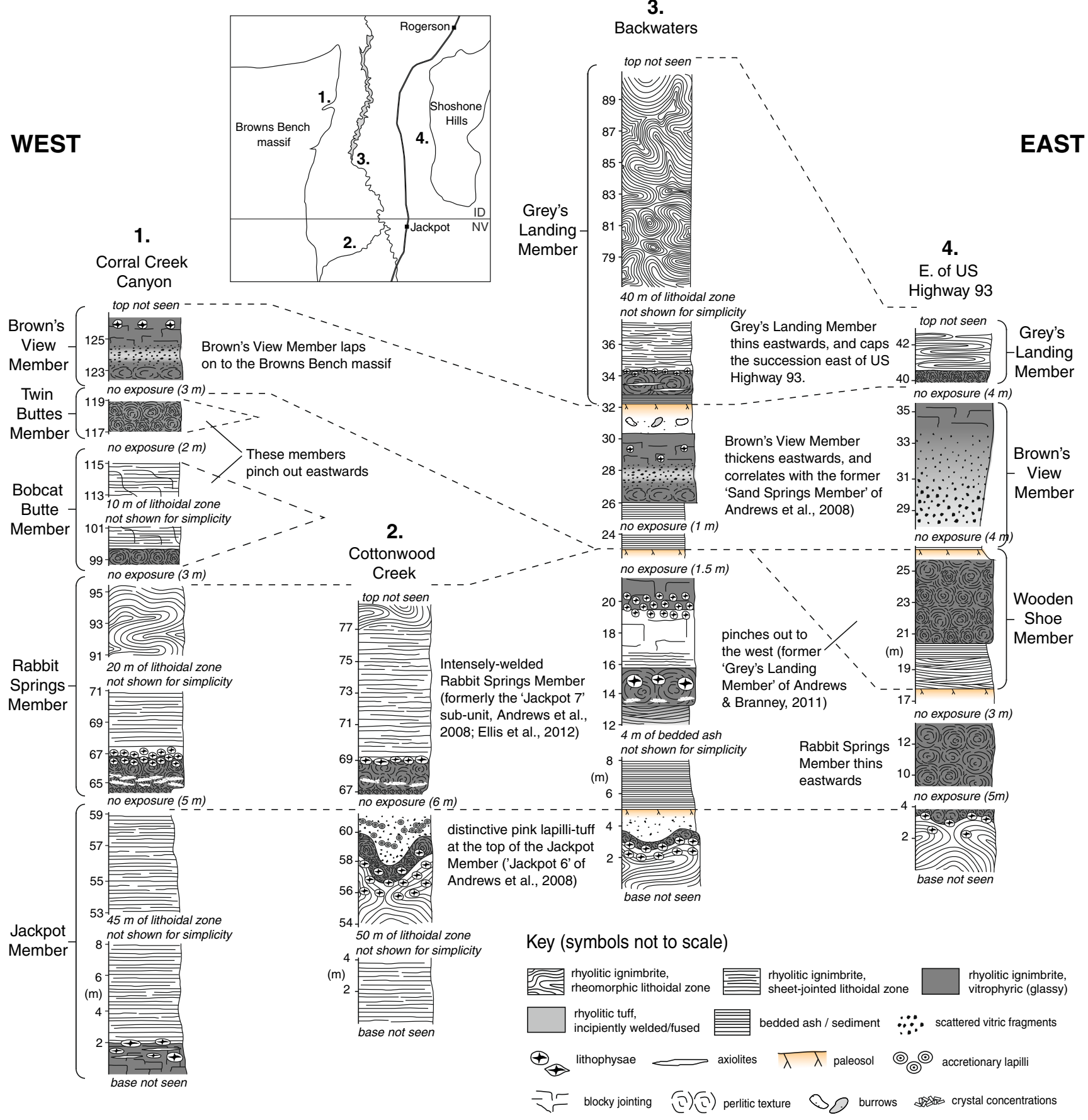

Fig. 7 West-to-East lateral variations in the upper part of the Rogerson Formation. Note how some ignimbrites thin and pinch out eastwards across the Rogerson Graben, whereas other units (Wooden Shoe and
Brown's View members) thin westwards. Lateral variations of older (pre-Jackpot Member) units are not evident within the Rogerson Graben
The lowest exposure is grey-black perlitic vitrophyric tuff, $1 \mathrm{~m}$ thick, containing angular vitric fragments $(\leq 4 \mathrm{~mm})$, similar to, but less abundant, than those in the Rabbit Springs Member. A zone of spherulites and lithophysae extends from the top of the vitrophyre into the sharply overlying sheet-jointed lithoidal zone, which has weathered to form prominent rounded erosional pillars. The lower lithoidal zone also contains sparse rotated lithic lapilli delta objects that indicate top-tothe-north rheomorphic transport directions (Fig. 8c). The Bobcat Butte Member contains two distinct compositional modes of pigeonite together with a single mode of augite, similar to the older Brown's Bench Member (Fig. 5). Its whole-rock chemistry is broadly similar to 

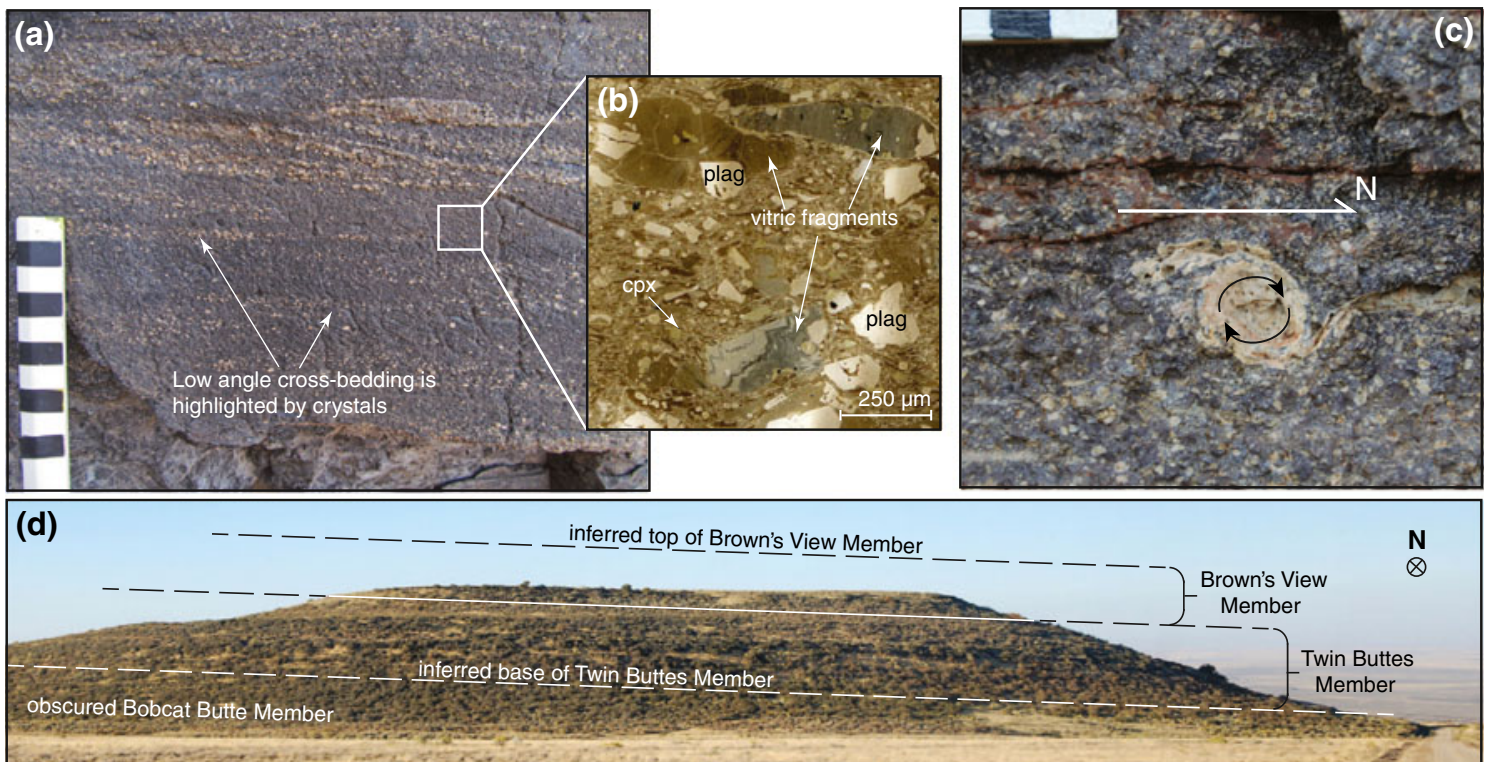

Fig. 8 a Lower vitrophyre of the Rabbit Springs Member with distinct low-angle cross-bedding highlighted by crystal (feldspar) concentrations. b Abundant vitric fragments also within the vitrophyre are only visible in thin section. c Rotated lithic lapillus delta object in the lower lithoidal zone of the Bobcat Butte Member indicating top-to-the-north shear, in the

its enclosing members but differs from the younger Twin Buttes Member by having lower $\mathrm{Nb}(<48 \mathrm{ppm})$ and lower $\mathrm{Rb} / \mathrm{Sr}$ ratios $(<2.2$, Fig. $3 b)$.

\section{Interpretation}

The ignimbrite doubles in thickness to $30 \mathrm{~m}$ northwards down-dip and is inferred to record a single hot, granular fluid-based density current, possibly from the NW, encroaching a north-dipping slope.

\section{Wooden Shoe Member}

The Wooden Shoe Member has not hitherto been recognised in the Rogerson area. It is defined at its type section within the Cassia Hills $\sim 40 \mathrm{~km}$ to the east (Knott et al. 2016). It has normal magnetic polarity and a distinct palaeomagnetic TRM direction shared only by the much younger Grey's Landing Member (Fig. 3a). In the Rogerson area, it is wellexposed along US Highway 93 (W on Fig. 1). At this location, it comprises a 3-m-thick basal non-welded stratified ash deposit overlain by a $\sim 5$-m-thick ignimbrite (Fig. 9a). It overlies an orange palaeosol at the top of the Rabbit Springs Member and is overlain by the eastern correlative of the Brown's View Member (Fig. 7). The lower white ash deposit has parallel-bedded ashfall layers including some reworked layers with low-angle scour surfaces. It includes a distinct reverse-graded pumice-fall layer, $20 \mathrm{~cm}$ thick, $\sim 1 \mathrm{~m}$ beneath the overlying ignimbrite, (Figs. 9a and probable downslope direction. d The Twin Buttes and Brown's View members are exposed on small mesas on Brown's Bench massif (Y on Fig. 1). Break in slope on the western side marks the top of the Twin Butte Member vitrophyre and the top of the mesa cuts at a shallow angle down through the Brown's View Member (Note: North is away from viewer)

10c): pumice fall (that is, containing pumice lapilli rather than just pumiceous ash) are scarce in Snake Rivertype deposits (Branney et al. 2008). The overlying ignimbrite is a massive, slightly perlitic vitrophyre. A eutaxitic fabric with $2-7 \mathrm{~cm}$ long fiamme is best seen on bleached joint surfaces in the lowermost $50 \mathrm{~cm}$.

The Wooden Shoe Member exposure on US Highway 93 (W on Fig. 1) has hitherto been thought to be the Grey's Landing Member (Andrews and Branney 2005; Andrews and Branney 2011), but its whole-rock trace elements (Figs. $3 \mathrm{~b}$ and 11c), pyroxene compositions (Figs. 5 and 11b) and the stratigraphy of the lower ashfall layer are inconsistent with the Grey's Landing Member (Fig. 10) and consistent with the Wooden Shoe Member. This has been confirmed by the discovery of the (younger) Grey's Landing Member (with its characteristic basal ashfall layer) further up-succession, just $3 \mathrm{~km}$ to the north (Fig. 9c) on the same highway (G on Fig. 1). Therefore, recent estimates of former ignimbrite rheology and cooling durations based on roadside site W (Lavallée et al. 2015; 'H' of Ellis et al. 2015) apply to the Wooden Shoe eruption.

\section{Interpretation}

The Wooden Shoe ignimbrite is a thinner, less-welded and non-rheomorphic distal part of a 45-m-thick, extensive rheomorphic ignimbrite further east that extends to Goose Creek, Nevada, and yields an ${ }^{40} \mathrm{Ar} /{ }^{39} \mathrm{Ar}$ age of 10.139 $\pm 0.006 \mathrm{Ma}$ (Knott et al. 2016). The distribution of the Wooden Shoe ignimbrite is now estimated to exceed $4400 \mathrm{~km}^{2}$, (Fig. 11e). Using measured thicknesses, this 
indicates a deposit volume of $\sim 130 \mathrm{~km}^{3}$. The thinner, nonrheomorphic, less-intensely welded nature of the unit in the Rogerson area is consistent with its appearance in southernmost Idaho, where it comprises a thin ( $1 \mathrm{~m}$ thick) vitrophyre (e.g. at Goose Creek, Knott et al. 2016). The fines-rich, basal laminated ash deposit contains abundant coated pellets further east, reflecting aggregation due to atmospheric moisture. This may record an early phreatoplinian phase of the explosive Wooden Shoe eruption.

\section{Twin Buttes Member}

The Twin Buttes Member ('BB-10' of Bonnichsen et al. 2008 ) is a $\geq 2$-m-thick rhyolitic ignimbrite sheet that overlies the Bobcat Butte Member near Twin Buttes and other small mesas west of the crest of Brown's Bench escarpment (type locality $2 \mathrm{~km}$ east of Twin Buttes; Y on Fig. 1). Only a 2-m-thick perlitic vitrophyre is exposed, and the member pinches out eastwards as it is absent in Rogerson Graben (Fig. 7). It has normal magnetic polarity and is separated from the overlying Brown's View Member by a $\sim 3 \mathrm{~m}$ gap in exposure (Fig. 2). Crystals (5-10\% and 1-2 $\mathrm{mm}$ in size) comprise a similar assemblage to other members, but the Twin Buttes Member conspicuously lacks sanidine, which is present in all underlying members, and has different augite and pyroxene compositions (Fig. 5) than those in the enclosing members. It has 70.4-72.3 wt.\% $\mathrm{SiO}_{2}$ and is distinctly lower in $\mathrm{Ba}(1079-1083 \mathrm{ppm})$ at elevated $\mathrm{Th}$ $(>31 \mathrm{ppm})$ contents than the underlying Bobcat Butte Member. The thin nature of this ignimbrite and its pinching out towards the SE suggests that it is a distal deposit from density current(s) derived from the NW, possibly during a period with relatively elevated topography to the SE.

\section{Interpretation}

The ignimbrite is inferred to record a single hot, granular fluidbased density current. Its limited exposure and thickness suggest that it may record a smaller volume eruption than other members of the formation. Alternatively it may be a more distal correlative of a more prominent ignimbrite further west.

\section{Brown's View Member}

The Brown's View Member is a rhyolitic ignimbrite with a compound vertical welding profile and a basal ashfall layer (Fig. 7) and is newly correlated as far as the Cassia Hills to the east (Fig. 11a), covering $\geq 3300 \mathrm{~km}^{2}$, with an estimated volume of $\sim 100 \mathrm{~km}^{3}$ (Fig. 11e). Its type locality is at Backwaters (Fig. 1), where it is $9 \mathrm{~m}$ thick and unconformably overlies a palaeosol in poorly exposed volcaniclastic sands above the Rabbit Springs Member (Andrews et al. 2008), and it is overlain by the Grey's Landing Member. It also forms two erosional benches above the Twin Buttes Member NW of Brown's Bench escarpment ('BBU-11' and '12' of Bonnichsen et al. 2008; Fig. 8d).

The parallel-bedded ashfall deposit is $3 \mathrm{~m}$ thick and comprises interbedded coarse to fine ash and pumice-fall layers. The ignimbrite has a lower perlitic vitrophyre, $1 \mathrm{~m}$ thick, overlain by less-welded lapilli-tuff, $1 \mathrm{~m}$ thick, with abundant non-vesicular vitric lapilli, $2-10 \mathrm{~mm}$ in size. Upward, the lapilli show inverse and then normal coarse-tail grading (Fig. 7). The welding intensity decreases towards the centre where the lapilli are largest and then increases upwards again towards an upper perlitic vitrophyre, $2 \mathrm{~m}$ thick, with sparse lithophysal spherulites, $1-2 \mathrm{~cm}$ in size. The upper vitrophyre is overlain by $2 \mathrm{~m}$ of non-welded, massive tan ash that is intensely bioturbated, with mammalian burrows. It is capped by a 0.5 -m-thick, terracotta-baked palaeosol with preserved

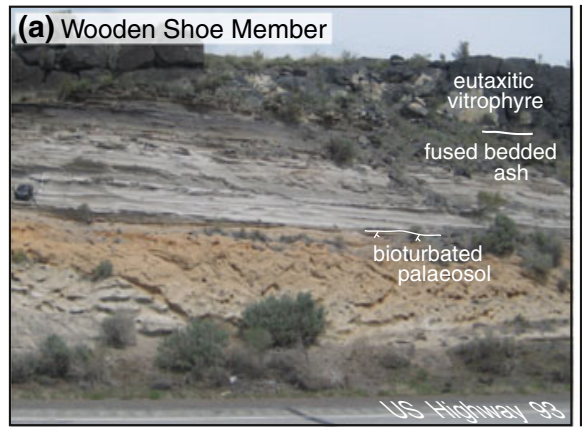

$\mathrm{s} \leftarrow$

Fig. 9 Three key exposures along US Highway 93, Idaho of a the thin eutaxitic Wooden Shoe ignimbrite (W on Fig. 1) vitrophyre overlies $3 \mathrm{~m}$ of bedded ashfall, with a distinct reverse-graded pumice fall (Fig. 10c) along with local scours and reworking. Here, the ignimbrite was previously misidentified as the Grey's Landing Member (Andrews et al.

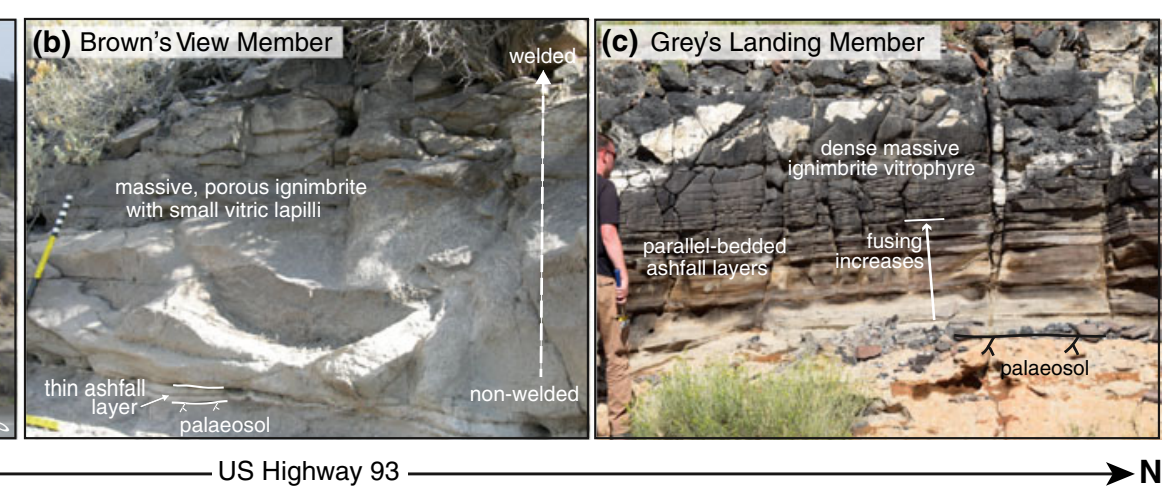

2008). b The Browns View Member, located $0.6 \mathrm{~km}$ further north (B on Fig. 1), is incipiently welded with a thin $(10 \mathrm{~cm})$ basal ashfall layer. c The thin Grey's Landing ignimbrite, which is here (G on Fig. 1) welded to a dense vitrophyre and overlies a parallel-stratified, partly fused ashfall deposit 

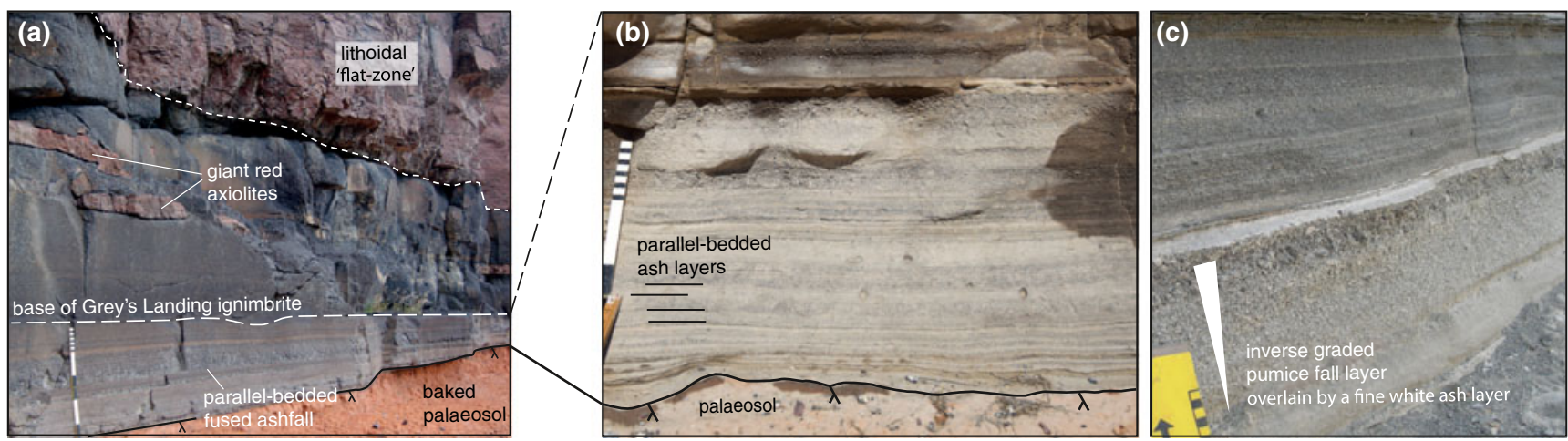

Fig. 10 Comparison of basal ashfalls beneath the Grey's Landing and Wooden Shoe Members. a At its type locality at Grey's Landing (Fig. 1), the Grey's Landing Member has a basal fused, parallel-bedded basal ashfall overlain by intensely welded ignimbrite containing distinct giant red axiolites. b Along US Highway 93 (G on Fig. 1), the Grey's Landing basal ashfall is much less fused (Fig. 9c) but retains the distinctive bedding observed at its type locality. c In contrast, the Wooden Shoe Member basal fall deposit (W on Fig. 1) has a non-welded reverse-graded pumice-fall layer, which readily distinguishes it from the younger Grey's Landing Member shown in (a) and (b) grass imprints on its upper surface. Ash up to $1 \mathrm{~m}$ below the soil has been intensely fused to dark vitrophyre by downward conduction of heat from the overlying intensely welded Grey's Landing ignimbrite (Andrews et al. 2008).

Crystal contents increase from $\sim 4 \%$ in the lower vitrophyre to $\sim 10 \%$ in the overlying lapilli-tuff and upper vitrophyre. Phenocrysts are plagioclase (1-2 $\mathrm{mm}$ in size), pigeonite, augite, magnetite and accessory apatite and zircon. Sanidine is absent, as with the locally underlying Twin Buttes Member. A distinct characteristic of the Brown's View Member is that pigeonite and augite $\mathrm{MgO}$ contents are higher than any other member of the formation (Figs. 5 and 11b). Whole-rock silica content (69$73 \mathrm{wt.} \%)$ is also the lowest in the Rogerson Formation, whereas $\mathrm{TiO}_{2}\left(\sim 0.65\right.$ wt.\%), $\mathrm{MgO}(\sim 0.50$ wt. $\%)$ and $\mathrm{Fe}_{2} \mathrm{O}_{3}$ ( 4.21 wt.\%) are relatively high (Online Resource 2 ).

On the northern Brown's Bench massif, the ignimbrite thins southwards from 11 to $4 \mathrm{~m}$ over $\sim 2 \mathrm{~km}$ away from the Snake River Plain. Within the Rogerson Graben, it thickens eastwards. Where the ignimbrite is thicker (e.g. East of US Highway 93, Z on Fig. 1), it overlies an eroded parallelbedded ashfall deposit $(10 \mathrm{~cm}$ thick, Fig. $9 \mathrm{~b})$ and comprises an 8-m-thick grey lapilli-tuff with a 1-m-thick upper vitrophyre (Fig. 7). The lapilli-tuff was previously thought to be the localised 'Sand Springs Member' (B on Fig. 1; Andrews et al. 2008). However, indistinguishable palaeomagnetic TRM directions (Fig. 3a inset i), together with whole-rock data and the distinctive high-MgO pyroxenes (Fig. 11b-d), indicate that these eastern outcrops are part of the Brown's View Member.

\section{Interpretation}

The Brown's View Member is correlated with the 'Little Creek Member' of the Cassia Formation (Knott et al. 2016) on the basis of (1) its stratigraphic position directly above the Wooden Shoe Member (Fig. 11a); (2) the same compound cooling unit profile, with upper and lower intensely welded zones separated by a less-welded lapilli-tuff containing abundant non-vesicular lapilli; (3) identical high-MgO ( 1014 wt.\%) pyroxenes that do not occur in other units (Fig. 11b); (4) consistent palaeomagnetism (Fig. 11d); and (5) consistent whole-rock chemistry (Fig. 11c). The name Browns View Member takes precedence as the earlier formerly establish nomenclature (Andrews et al. 2008). The thicker exposures of the member in the Cassia Hills (Knott et al. 2016) may indicate that they were topographically lower than Rogerson Graben at the time of eruption.

The eruption began with ashfall from an unsteady eruption column. The parallel ashfall layering likely reflects some combination of fluctuating eruption column height and localised ash showering initiated by convective instabilities in lower parts of the umbrella region of the eruption plume (e.g. Carey et al. 1988; Branney 1991). A sustained, hot pyroclastic density current then flowed across the region. The initially upward-increasing abundance and size of non-vesicular, blocky vitric lapilli in the ignimbrite may reflect waxing flow competence and/or increasing entrainment of these fragments at source, which peaked and then gradually decreased (e.g. waning flow) as recorded by the decrease in the fragments towards the top of the unit. The welding intensity shows an inverse relationship with the abundance of non-vesicular blocky lapilli in vertical sections. This suggests that the influx of the blocky clasts during the middle part of the eruption was associated with a phase of cooling of the density current, probably in a similar manner to that outlined above for the Brown's Bench and Jackpot eruptions.

\section{Grey's Landing Member}

The Grey's Landing Member is the youngest and most rheomorphic member of the Rogerson Formation. The 
(a) Rogerson area

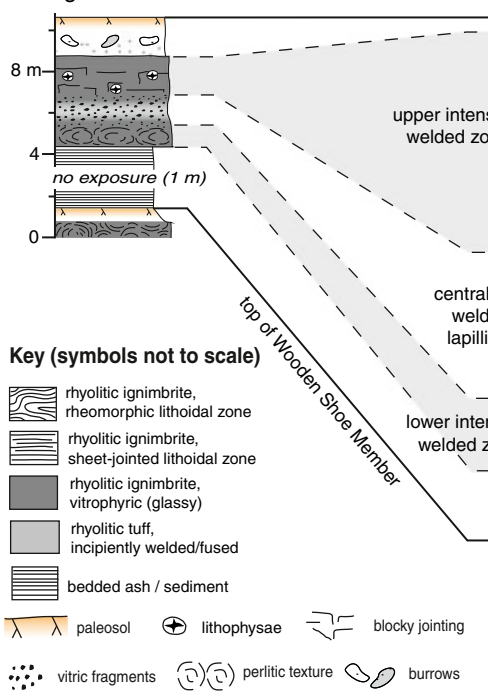

Cassia Hills $4+4$

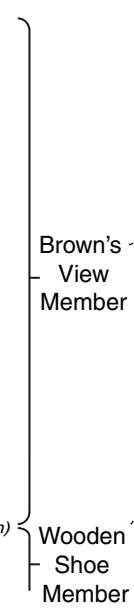

(b)

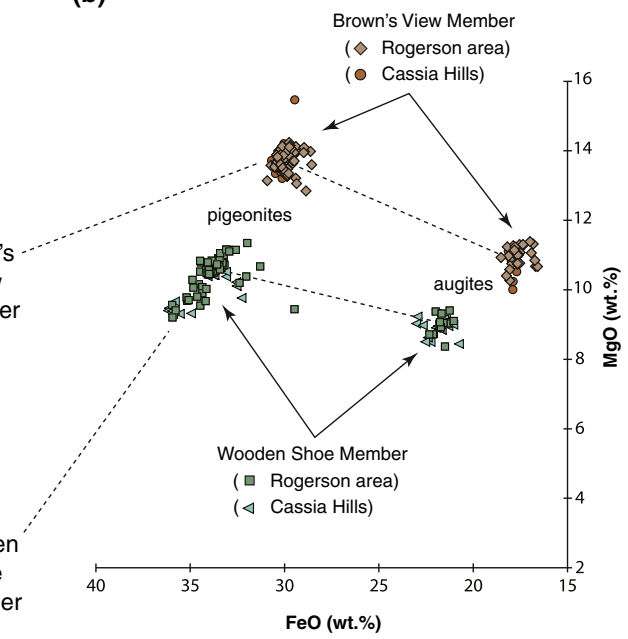

(c)

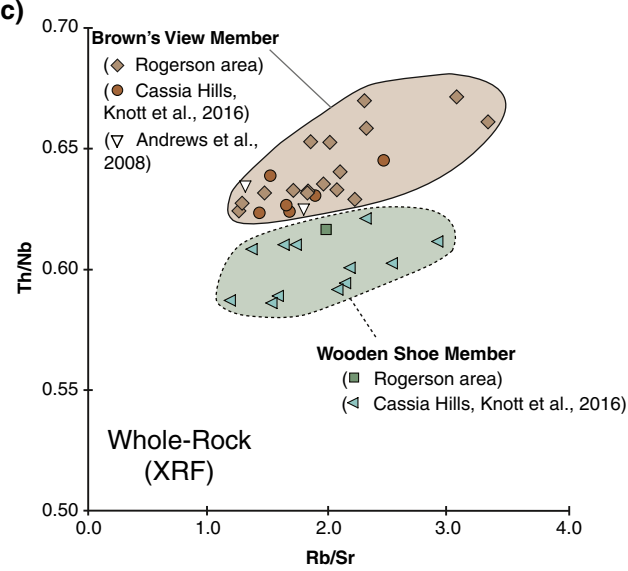

(d)

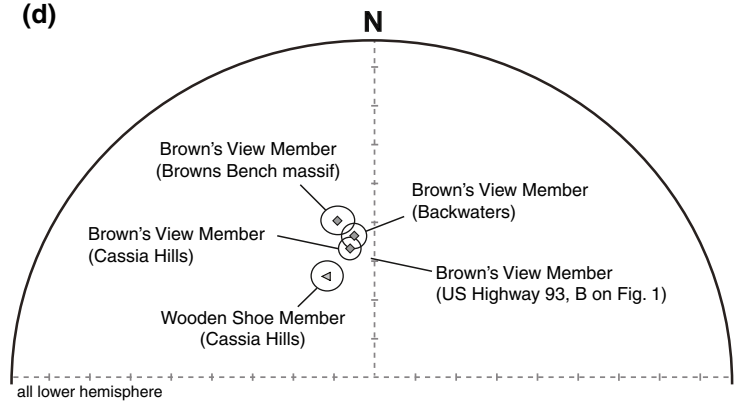

(e)

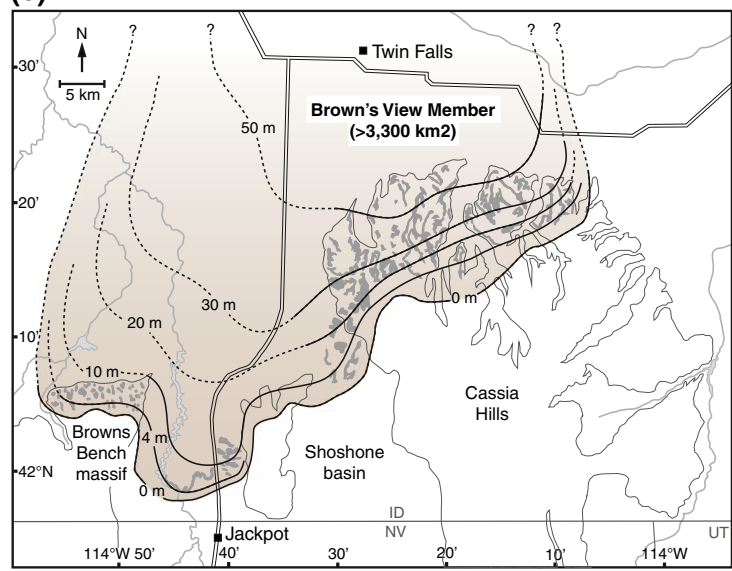

Fig. 11 Distinct correlation characteristics of the Browns View and Wooden Shoe members. a Graphic logs of the Brown's View Member at Backwaters and the Cassia Hills (formerly 'Little Creek Member' of Knott et al. 2016) showing the correlation between the distinct lithofacies of this compound ignimbrite as it thins westwards. b Distinction between high-MgO pyroxenes of the Brown's View ignimbrite and those of the underlying Wooden Shoe Member. c Whole-rock $\mathrm{Rb} / \mathrm{Sr}$ versus $\mathrm{Th} / \mathrm{Nb}$ data indicating discrete chemical fields between the two members

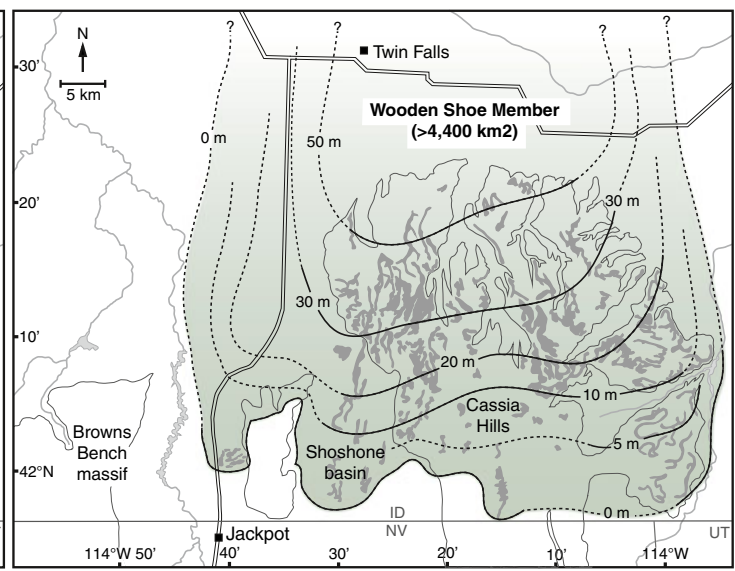

(Cassia Hills data are from Knott et al. 2016). d Site mean TRM directions (corrected for post-emplacement tectonic dips) for the Brown's View Member are consistent between correlatives and distinct from the underlying Wooden Shoe Member. e Inferred distributions of the Brown's View and Wooden Shoe members in the central Snake River Basin, with known and inferred thickness contours yielding conservative volume estimates of $\sim 100$ and $\sim 130 \mathrm{~km}^{3}$, respectively 
ignimbrite has been well described and interpreted because it has been influential in the understanding of how rhyolitic rheomorphic ignimbrites are emplaced, rapidly welded, deformed and cool (Branney et al. 2004; Branney et al. 2008; Andrews et al. 2008; Andrews and Branney 2011; Robert et al. 2013; Finn et al. 2015; Ellis et al. 2015). However, previous accounts included nearby exposures (W on Fig. 1) of what is now known to be the older Wooden Shoe Member (Fig. 9a). The present revision of the stratigraphy reveals that the member has more consistent distinguishing field, chemical and mineralogical characteristics than was formerly thought.

At its type section at Grey's Landing (Fig. 1), a $\geq 65$-m-thick intensely rheomorphic, lava-like ignimbrite (top not seen), with a fused basal ashfall layer, overlies a baked palaeosol in the Brown's View Member (Fig. 2; Fig. 10a). The upper contact is best seen at Salmon Falls Reservoir dam (Fig. 1), where an upper vitrophyric and partly pumiceous, rheomorphic autobreccia and overlying orange ash are overlain by a 30cm-thick soil baked red by overlying younger basalt lavas.

The Grey's Landing Member differs from others in the Rogerson Formation in containing four discrete compositional modes of pyroxene (two augite-pigeonite pairs, Fig. 5). The crystal content $(10-15 \% ; 1-3 \mathrm{~mm}$ in size) is consistent throughout and also contains plagioclase, magnetite and accessory apatite and zircon, but it lacks sanidine.

The basal ashfall layer, $0.5 \mathrm{~m}$ thick, is thin parallel-bedded with alternating crystal-rich and vitric layers, all fused to dense vitrophyre by the overlying ignimbrite (Fig. 10a; Andrews and Branney 2011). The ignimbrite has a massive perlitic basal vitrophyre, $2 \mathrm{~m}$ thick, in which microscopic shards are both compacted and highly attenuated (Andrews and Branney 2011) to form a crystal-wrapping foliation that ranges from parataxitic to flow-banded. Sparse ellipsoidal vesicles, $<2 \mathrm{~cm}$ in size, have grown by late exsolution of the tuff following welding, and red planar devitrification zones (giant axiolites; $2 \mathrm{~cm}$ thick and $<3 \mathrm{~m}$ long) have locally overprinted the welding fabric (Fig. 10a).

The overlying, red-brown, lithoidal zone is c. $57 \mathrm{~m}$ thick and has a lower 'flat-zone' with sub-horizontal intrafolial isoclines and sheath folds and an upper 'steep-zone' with upright to overturned $\geq 10 \mathrm{~m}$ scale antiforms and synforms that refold the earlier isoclines (Branney et al. 2004; Andrews and Branney 2011). The upper vitrophyre, $\geq 1 \mathrm{~m}$ thick, is perlitic, locally highly inflated by post-welding vesiculation, and folded into tight upright folds with rheomorphic autobrecciation. A porous upper orange ash, 2-3 m thick, is preserved within rheomorphic synclines and is locally fused at the contact with the vitrophyre.

West of Rogerson Graben, the ignimbrite thins rapidly and pinches out southwards from the Snake River Plain $(3 \mathrm{~km} \mathrm{~N}$ of Twin Buttes, Fig. 1), but within the graben, it extends $14 \mathrm{~km}$ further south to Backwaters and thins eastwards from $>65 \mathrm{~m}$ to $\sim 4 \mathrm{~m}$ thick, where it is still entirely welded and intensely rheomorphic. A 5-m-thick eutaxitic vitrophyre on US Highway 93 (W on Fig. 1; Fig.9a) was thought to be a thin less-intensely welded Grey's Landing Ignimbrite (Andrews et al. 2008; Andrews and Branney 2011). However, this outcrop has a contrasting basal ashfall sequence (Fig. 10) and is now known to be part of the Wooden Shoe Member (see above; Fig. 7). The true Grey's Landing ignimbrite outcrops just $3 \mathrm{~km}$ further north ( $\mathrm{G}$ on Fig. 1), where it was hitherto not described (Fig. 9c). Here, the same parallel-bedded basal ashfall sequence as at the type area is seen (Fig. 10b), overlain by a 1m-thick massive basal vitrophyre that lacks fiamme, sharply overlain by a lithoidal rheomorphic zone ( $\geq 2 \mathrm{~m}$ thick; top not seen). The thinned ignimbrite also caps several small mesas east of the highway. This correlation is supported by indistinguishable trace element data (Fig. 3b), palaeomagnetic TRM directions (Fig. 3a, inset i) and the characteristic of two pyroxene pairs (Fig. 5).

\section{Interpretation}

There is no evidence for any significant break during the emplacement of the Grey's Landing Member and it is inferred to record a single eruption (Andrews and Branney 2011). Unsteady ash fallout from the first plinian phase of the eruption was followed by a protracted, and geographically extensive, intensely hot pyroclastic density current. During deposition, hot ductile pyroclasts coalesced and sheared around the base of the current with the development of a ductile shear zone that rose with the rising surface of the aggrading deposit (see Branney and Kokelaar 1992). The shear zone produced pervasive mylonite-like fabrics, extensional lineations and subparallel intrafolial sheath folds. The orientation of these features gradually changes with height in the ignimbrite, reflecting shifting rheomorphic transport directions with time as the ignimbrite gradually aggraded (Branney et al. 2004). Such rapid welding and rheomorphic shear during emplacement is consistent with rheology and geospeedometry estimates (Robert et al. 2013; Lavallée et al. 2015, although the site sampled is now identified as the Wooden Shoe Member). Gravity-driven, hot deformation continued after deposition ceased, folding the first generation fabrics and folds, and causing local autobrecciation, particularly in the upper vitrophyre, which chilled more rapidly. This is consistent with modelled cooling rates (Ellis et al. 2015). The upper non-welded orange ash records late-stage, cooler emplacement onto the still hot and moving rheomorphic ignimbrite, as indicated by the localised folding and fusing of the upper ash, where it is in contact with the ignimbrite's upper vitrophyre (Andrews and Branney 2011). A detailed magnetic study of the member demonstrates that rheomorphic shear fabrics influence the orientation of thermoremanent magnetisation, particularly in the lower vitrophyre, but a consistent palaeomagnetic field (Fig. 3a) nevertheless can be discerned with careful sampling and analysis (Finn et al. 2015). 


\section{Whole-rock and mineral chemistry}

This section describes the chemistry of the Rogerson Formation primarily to help characterise and distinguish the individual members. The stratigraphic approach has enabled the resolution of temporal trends in the rhyolite chemistry.

Rogerson Formation ignimbrites are metaluminous to slightly peralkaline rhyolites $\left(69.4-76.6 \mathrm{wt} . \% \mathrm{SiO}_{2}\right)$, with typical alkali saturation indices (ASI) ranging between 0.71 and 1.05 (Online Resource 2). Their whole-rock chemistry resembles that of other central Snake River Plain ignimbrites (Bonnichsen and Citron 1982; Wright et al. 2002; Bonnichsen et al. 2008; Ellis et al. 2012) with less than 0.8 wt. $\% \mathrm{TiO}_{2}$, elevated $\mathrm{Fe}_{2} \mathrm{O}_{3}(5.09-1.27$ wt.\%) and low $(<0.8$ wt. \%) MgO (Online Resource 2$)$. Vertical chemical zonation within individual members is minimal, with typical base to top variations of $<2 \mathrm{wt} . \% \mathrm{SiO}_{2}$ at any one locality. The lack of significant chemical zonation is a distinctive feature of these Snake River-type ignimbrites, in comparison to some other medium to large-volume ignimbrites (e.g. Hildreth 1979). Most Rogerson Formation ignimbrites have a common central Snake River Plain anhydrous mineral assemblage comprising some or all of plagioclase, sanidine, pigeonite, augite, quartz, olivine, magnetite, ilmenite and accessory zircon and apatite (Ellis et al. 2013). Biotite and amphibole (as in 'Lava Creek Tuff Member A' of Yellowstone; Christiansen 2001) and secondary amphibole rims on augites (as in some Cougar Point Tuffs; Bonnichsen and Citron 1982) are not observed. Most of the ignimbrites contain both pigeonite and augite, and the compositions of these helps distinguish the members. In addition, several ignimbrites contain more than one type of pigeonite (e.g. the Browns Bench Member; Fig. 5) and/or more than one type of augite (e.g. the Grey's Landing Member; Fig. 5). This is interpreted as indicating the simultaneous eruption of more than one magma composition, as proposed for rhyolitic ignimbrites elsewhere in the central Snake River Plain (Cathey and Nash 2004; Ellis and Wolff 2012; Ellis et al. 2014).

\section{Chemical and mineralogical trends with time}

Using the stratigraphy outlined above, the Rogerson Formation records two opposing geochemical trends (Fig. 12). Up-succession from the Brown's Bench Member to the China Hill Member, whole-rock $\mathrm{SiO}_{2}$ contents increase, whereas $\mathrm{TiO}_{2}, \mathrm{Ba}$ and $\mathrm{Zr}$ contents decrease (Fig. 12), as do pyroxene $\mathrm{Mg}$-numbers and plagioclase anorthite contents (Fig. 12). These whole-rock and mineralogical trends are consistent with a normal 'maturation' of the magmatic system due to cooling and crystal fractionation (e.g. successively higher $\mathrm{SiO}_{2}$, Fig. 12). The degree of fractional crystallisation required to account for this chemical progression is $\sim 20 \%$; assuming a low pressure fractionating assemblage comprising feldspar, pyroxenes, magnetite and zircon (modal proportions 45:50:5: $<1$; respectively). In contrast, younger units (Jackpot to Brown's View members) show decreasing $\mathrm{SiO}_{2}$ and increasing $\mathrm{TiO}_{2}, \mathrm{Ba}$ and $\mathrm{Zr}$ with stratigraphic height (Fig. 12). This is accompanied by an upward increase in pyroxene $\mathrm{Mg}$ numbers. This second trend indicates a progression towards less-evolved rhyolite compositions with time: similar progressions have been noted regionally (Nash et al. 2006; Bonnichsen et al. 2008) and within the Cassia Hills Formation to the east, where they are attributed to cyclic petrogenetic processes (Knott et al. 2016). It is possible that repeat injections of mantle-derived basaltic melts into the midcrust drove melting of a hybridised (diorite?) source region (Leeman et al. 2008; McCurry and Rodgers 2009), with prolonged melting and hybridisation yielding progressively less differentiated rhyolitic magma batches that then erupted (Knott et al. 2016). The youngest, Grey's Landing Member discontinues the trend towards less-evolved rhyolites and has higher $\mathrm{SiO}_{2}$ and lower pyroxene $\mathrm{Mg}$-numbers similar to the older Black Canyon Member (Fig. 12). This abrupt shift may mark the start of a new geochemical cycle, due to migration of the locus of crustal melting and hybridisation as the Yellowstone hotspot shifted eastwards (Knott et al. 2016).

\section{Tectonic evolution of Rogerson Graben}

The 15-km-wide Rogerson Graben in southern Idaho trends N-S and opens to the Snake River Basin in the north, and in the south, it opens into a basin south of Jackpot, Nevada (Fig. 1). Interest lies in its association with voluminous magmatism: the graben developed between $\sim 12$ and $8 \mathrm{Ma}$, when magmatic activity beneath the central Snake River Plain was at a peak (Nash et al. 2006; Bonnichsen et al. 2008) and the 70-km-wide west Snake River rift (Fig. 1) was forming by NE-SW extension (Bonnichsen and Godchaux 2002; Beranek et al. 2006; Andrews et al. 2008).

The graben is bound by two normal faults: (1) the Edownthrowing, 30-km-long Brown's Bench Fault in the west that produced the 400-m-high Brown's Bench escarpment and (2) the smaller Shoshone Hills Fault in the east (Fig. 1, Andrews et al. 2008). NNW and NNE-trending faults within the graben are growth faults, active both during and after ignimbrite-forming eruptions. Westward thickening of successive Rogerson Formation members within the graben was interpreted to record the progressive development of an asymmetric half-graben with a westward-dipping floor (Andrews et al. 2008). The present paper draws on the revised stratigraphy to reconstruct a more complex graben evolution (Fig. 13), using the principle that ignimbrites behave 
essentially the same way as turbidites and thickness variations largely reflect the evolution of basin-floor topography. Ignimbrites typically fill and bury topographic depressions producing nearly flat upper surfaces (Branney and Kokelaar 2002). They also partly drape substrate slopes yielding upper surfaces that dip up to $5^{\circ}$ (e.g. depositional ramps of Suzuki-Kamata and Ui 1982), which may then steepen further during postdepositional welding compaction. Consequently, thickness variations within an ignimbrite sheet indicate, but are more subdued than, the topographic relief of the basin at the time of emplacement. In the Rogerson Graben, thickness variations caused by Miocene erosion can generally be excluded: the upper vitrophyres are widely preserved with little incision. It seems that the intense welding favoured intact preservation.

\section{Stage 1: initial uplift in the East ( 11.0-10.3 Ma)}

The Rabbit Springs Member thins eastwards from 30 to $8 \mathrm{~m}$ across the Rogerson Graben. This contrasts with the underlying Jackpot Member, which exhibits no obvious thickness changes across the graben faults, and so probably pre-dates much of the faulting. These thickness changes suggest that a gentle west-facing topographic slope (Fig. 13a) started to increase between 10.96 $\pm 0.01 \mathrm{Ma}$ and $10.49 \pm 0.13 \mathrm{Ma}$ (ages of the Jackpot and Rabbit Springs members), causing the Rabbit Springs ignimbrite to pond in the west and thin and offlap upslope to the east (Fig. 13a). Continued rise of the early Shoshone Hills in the east prior to 10.34 $\pm 0.09 \mathrm{Ma}$ (age of the Bobcat Butte Member) is indicated by progressive offlap of two younger ignimbrites: the Bobcat Butte and Twin Buttes members thin and pinch out eastward between the Brown's Bench massif and Backwaters (Figs. 13b and 7).

\section{Stage 2: development of an E-sloping half-graben ( 10.3-10.1 Ma)}

The slope of the floor of Rogerson Graben then reversed, as indicated by ponding of the Wooden Shoe Member in the east, and its absence further west (e.g. at Backwaters; Fig. 7). The younger Brown's View Member thickens slightly from $\sim 10$ to $\sim 14 \mathrm{~m}$ eastward across the graben (Fig. 7). We infer that E-W extension initiated the Shoshone Hills Fault system, removing the westward basin slope and forming a gentle eastward dipping half-graben (Fig. 13c). The initiation of Shoshone Hills faulting pre-dated $10.139 \pm 0.006 \mathrm{Ma}$, the age of the Wooden Shoe Member.

\section{Stage 3: activation of the W-sloping Rogerson Graben ( 10.1-8.0 Ma)}

Activation of the Brown's Bench Fault to produce a second slope reversal (Fig. 13d) is indicated by marked thickening of the Grey's Landing Member ignimbrite ( 8.0 Ma) from 3 to $65 \mathrm{~m}$ towards the west side of Rogerson Graben (Fig. 13f), together with the absence of the ignimbrite on Brown's Bench massif on the western, upthrown, side of the fault. A westsloping graben floor is consistent with kinematic indicators and $\mathrm{W}$-trending extensional rheomorphic lineations in the (a)

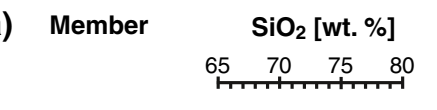
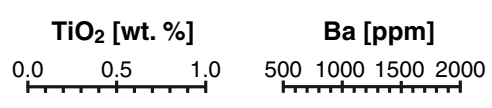
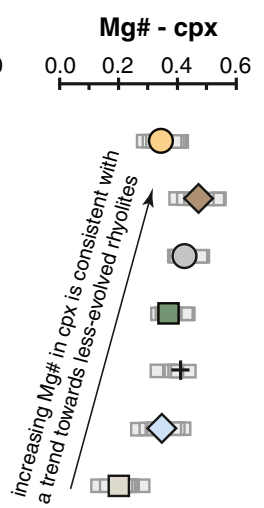

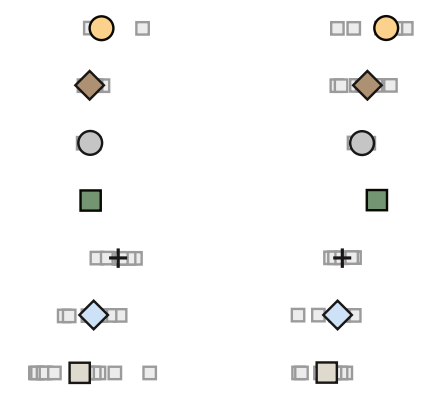

11. Grey's Landing
10. Brown's View
9. Twin Buttes
8. Wooden Shoe
7. Bobcat Butte
6. Rabbit Springs
5. Jackpot

4. China Hill

3. Black Canyon

2. Brown's Bench

1. Corral Creek

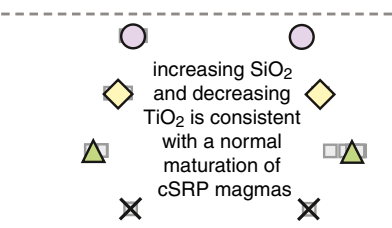

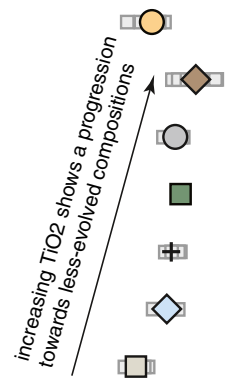
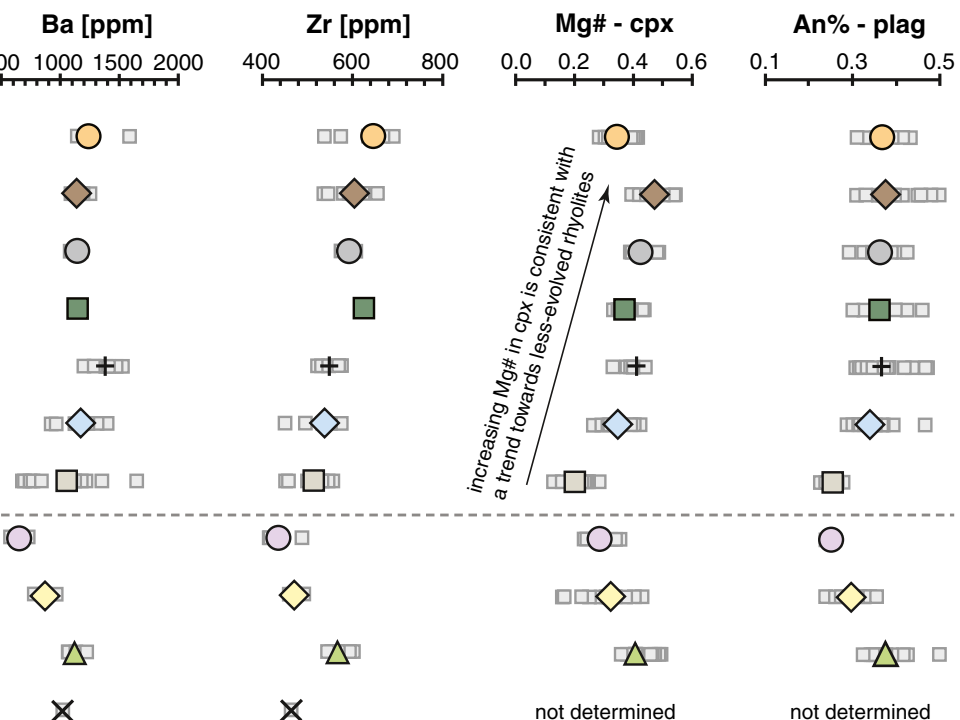

not determined

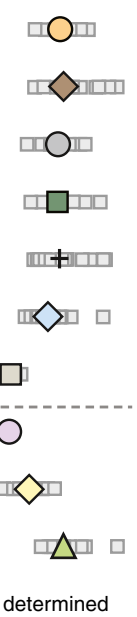

onset of trends towards less-evolved compositions is indicated by dashed line). Bold, coloured symbols denote mean compositions (grey squares indicate individual sample compositions)

of Rogerson Formation members. Plots of select whole-rock major and trace elements, along with pyroxene ( $c p x)$ and plagioclase (plag) data (the 
Grey's Landing ignimbrite across the graben, indicating topto-the-west, downslope hot rheomorphic shear (Andrews and Branney 2005; 2011). We infer a phase of E-W extension prior to emplacement of the Grey's Landing ignimbrite with faulting predominantly on the Brown's Bench Fault (Fig. 13d).

\section{Stage 4: continued displacement on the Brown's Bench Fault ( 8.0 Ma—present)}

Displacement on the Brown's Bench Fault continued after the Grey's Landing eruption to produce the present-day 400-mhigh Brown's Bench Fault escarpment (Fig. 13e). LateMiocene basalt lavas (Bonnichsen and Godchaux 2002) partly flowed over the subdued northern extension of the scarp but also show evidence of dip-slip offset west of Salmon Dam (Fig. 1). Smaller NW-SE trending graben cut late-Miocene basalts in the north of Rogerson Graben (Fig. 1). These graben trend towards the west Snake River rift and likely represent its southern extension, with opening possibly continuing into the Quaternary. The young (probably $<1 \mathrm{Ma}$ ) Salmon Butte shield volcano (Fig. 1) is sited at the intersection of faults associated with western Snake rifting and fractures associated with the Brown's Bench monocline (below): Pliocene-Pleistocene lavas from the volcano flowed into the Salmon River canyon, and so post-date incision, and also into one of the NWtrending graben, and so post-date the late extensional faulting. The lavas are Ti- and Fe-rich basalts similar to ferrobasalts of the western Snake River rift. Quaternary fans south of Jackpot suggest that the region remains tectonically active.

\section{Snake River Basin subsidence and timing of the Brown's Bench monocline}

The $100 \times 600 \mathrm{~km}$ Snake River Basin is thought to have subsided in response to loading by the emplacement of a large mid-crustal mafic sill, accommodated by lower-crustal flow into basin-and-range-extending crust to the north and the south (Sparlin et al. 1982; Leeman et al. 2008), supplemented by subsidence of large calderas (Branney et al. 2008). In the eastern Snake River Plain, the loading origin is indicated by the presence of a 10-km-thick seismic high-V $p$ lens (Peng and Humphreys 1998; Shervais et al. 2006). There, basinal strata have subsided $\sim 5 \mathrm{~km}$ relative to their elevation on flanking massifs (McQuarrie and Rodgers 1998; Rodgers et al. 2002).

Around Rogerson, the southern margin of the Snake River Basin is defined by a gentle north-dipping monocline, partly buried by younger basalt lavas within the graben, but clearly exposed on the Brown's Bench Fault escarpment, where the monocline is defined by the changing dips of Rogerson Formation ignimbrites (Fig. 14). The Brown's Bench monocline forms a westward continuation of the Cassia monocline (Knott et al. 2016) and has an opposing monocline along the northern margin of the central Snake River Basin (Mount Bennett Hills, Idaho).

The upper sub-horizontal limb of the Brown's Bench monocline extends south into northern Nevada from near the summit of the Brown's Bench massif, west of Backwaters (Fig. 1). The tilted limb dips $3-5^{\circ} \mathrm{N}$ and extends northwards at least $12 \mathrm{~km}$ before it dips beneath younger deposits ponded in the Snake River Basin. Several small-displacement E-Wtrending faults (Fig. 1) cut the northern limb of the monocline: their trend parallel to the axial trace of the monocline suggests they are formed by outer-arc extension.

The differential elevation across the Brown's Bench monocline is estimated at $\sim 4-5 \mathrm{~km}$, using the well-exposed Rabbit Springs Member as a reference horizon (Fig. 14e inset), which projects northward beneath the northward-thickening Bobcat Butte, Twin Buttes, Browns View and Grey's Landing members (Fig. 14e) and also beneath several post-Rogerson Formation units (e.g. Castleford Crossing Ignimbrite, $70 \mathrm{~m}$, Balanced Rock Rhyolite lava, $80 \mathrm{~m}$; Late-Miocene and Pliocene to Pleistocene basalts, $\geq 100 \mathrm{~m}$, Bonnichsen et al. 2008; Othberg et al. 2012). The net differential elevation across the Brown's Bench monocline could exceed our estimate if, as we expect, some individual ignimbrites reach over $1 \mathrm{~km}$ thick in the Snake River Basin, as demonstrated by a $\geq 1.3-\mathrm{km}$-thick ponded ignimbrite in the Kimberly deep drill core to the east (Shervais et al. 2013; Knott et al. 2016). Similar estimates of elevation change across the basin margins are described in the eastern Snake River Plain (Rodgers et al. 2002) and around Kimberly (Knott et al. 2016).

The timing of Snake River Basin subsidence in the Rogerson area is constrained by the ignimbrites on Brown's Bench monocline. The $10.59 \pm 0.09$ Ma Rabbit Springs Member forms the crest of Brown's Bench escarpment and maintains its thickness ( $\sim 30 \mathrm{~m})$ from the summit of the massif northward down the steep limb of the monocline (Fig. 14e). We infer from this that little subsidence of the Snake River Basin pre-dated $10.59 \pm 0.09 \mathrm{Ma}$ (Fig. 14a). In contrast, the overlying Bobcat Butte Member (10.34 $\pm 0.09 \mathrm{Ma})$ doubles in thickness northwards down the steep limb and pinches out $\sim 3 \mathrm{~km}$ south of Corral Creek. This indicates a response of pyroclastic density currents to a new north-facing slope and so marks the initiation of Snake River Basin subsidence in the Rogerson area between 10.59 and 10.34 Ma (Fig. 14b). The younger ignimbrites on Brown's Bench massif also thin and ultimately pinch out up the north-dipping limb of the monocline. The Brown's View ignimbrite thins abruptly southward and pinches out further north $(\sim 1 \mathrm{~km}$ south of Twin Buttes; Fig. 1) than the Bobcat Butte Member (Fig. 14c). Within the developing Rogerson Graben, however, it was able to extend much further south (e.g. $\geq 4 \mathrm{~m}$ thick at Backwaters). This pattern confirms that distribution and thickness changes of the ignimbrite generally reflect subsidence topography rather 
(a) 10.59 Ma: Rabbit Springs eruption

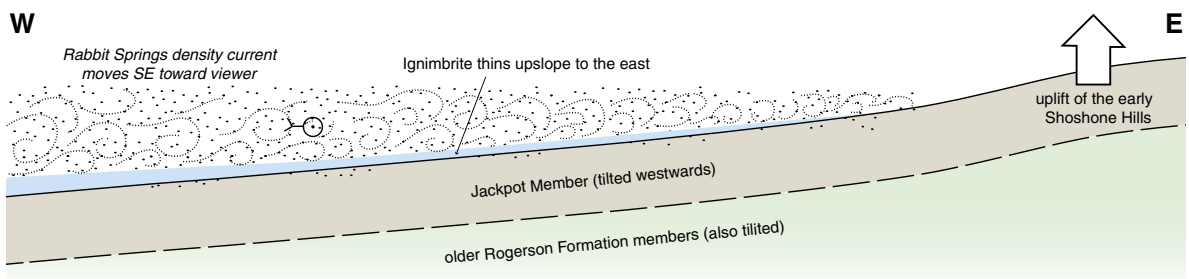

(b) $\sim 10.34 \mathrm{Ma}$ : Bobcat Butte eruption

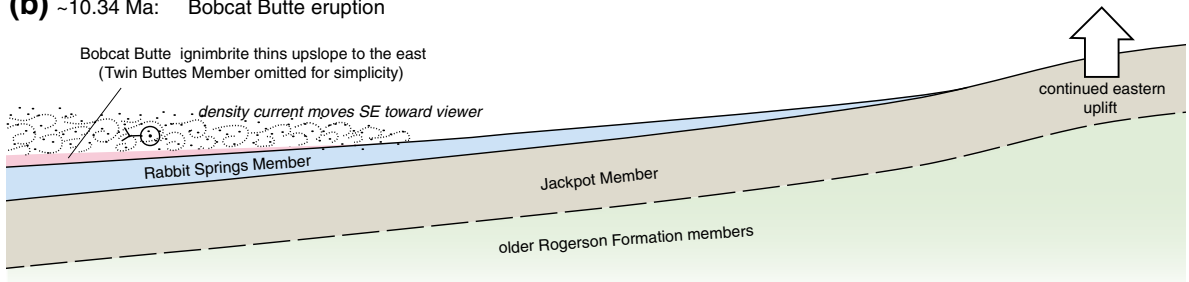

(c) 10.13 - 10 Ma: Wooden Shoe and Brown's View eruptions eastern faults with westerly downthrow
developing an asymmetric half-graben prior to the Brown's View eruption
.

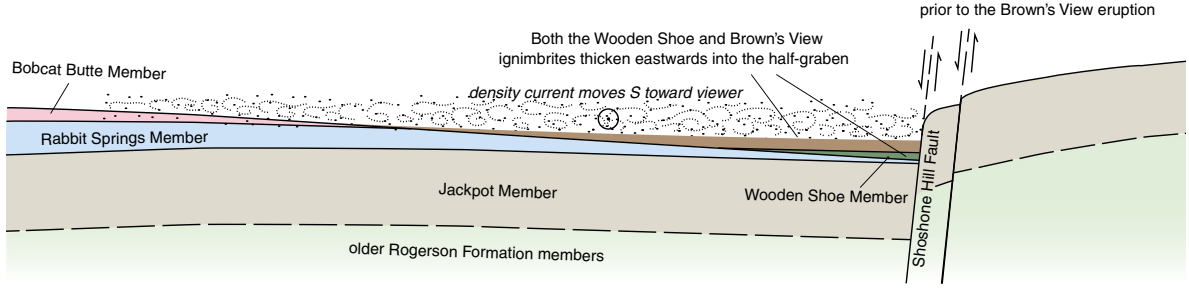

(d) 8.0Ma: Grey's Landing eruption

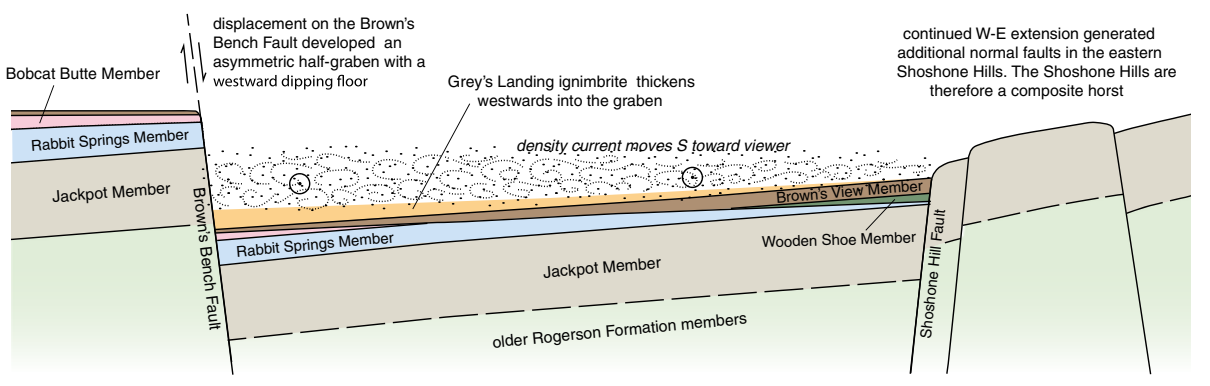

(e) 8.0 Ma present: Continued displacement on the Brown's Bench Fault
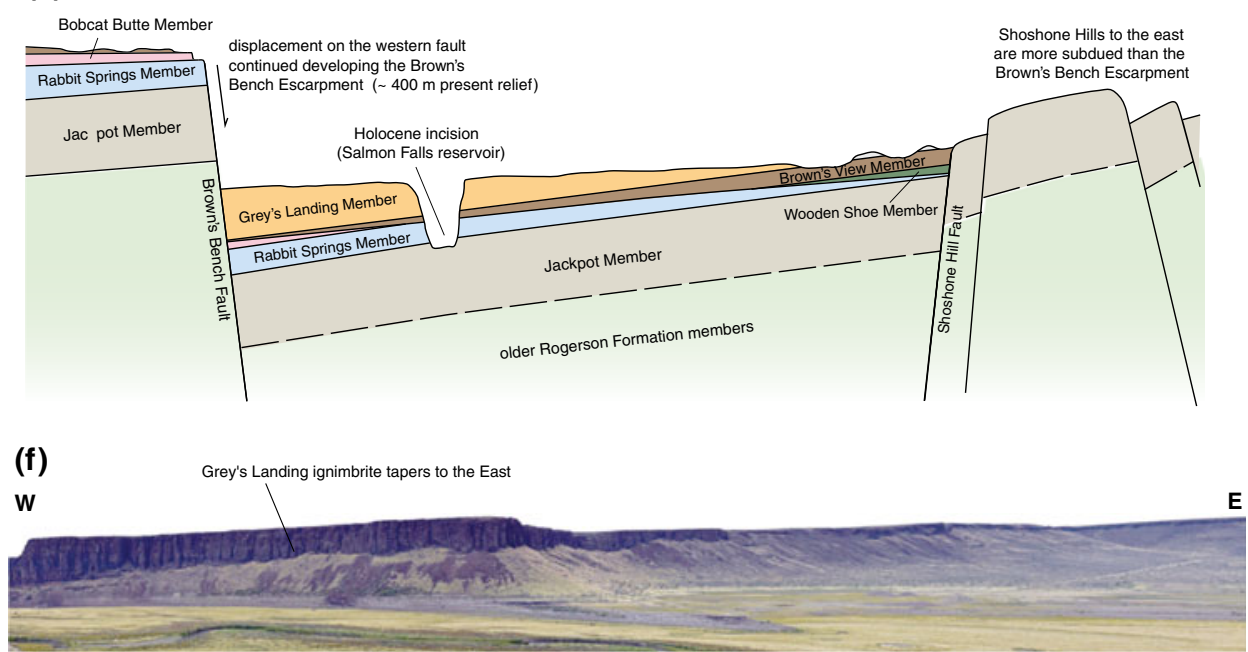

Fig. 13 Tectonic evolution of the Rogerson Graben as a series of progressive stages (from 10.59 to $8.0 \mathrm{Ma}$; a-e) that account for lateral thickness variations of ignimbrites of the Rogerson Formation. $\mathbf{f}$ Eastward thinning of the Grey's Landing Member at Backwaters 
(a) $10.59 \mathrm{Ma}$ - Rabbit Springs eruption

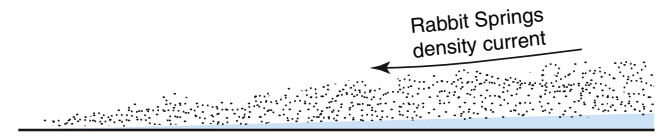

earlier Rogerson Formation members (b) $10.34 \mathrm{Ma}$ - Bobcat Butte eruption

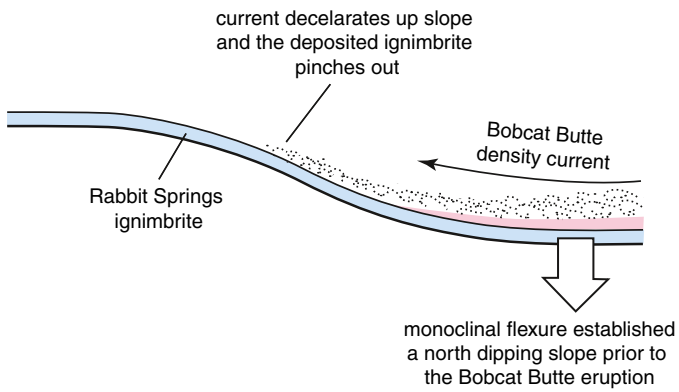

(d) 8 Ma - Grey's Landing eruption

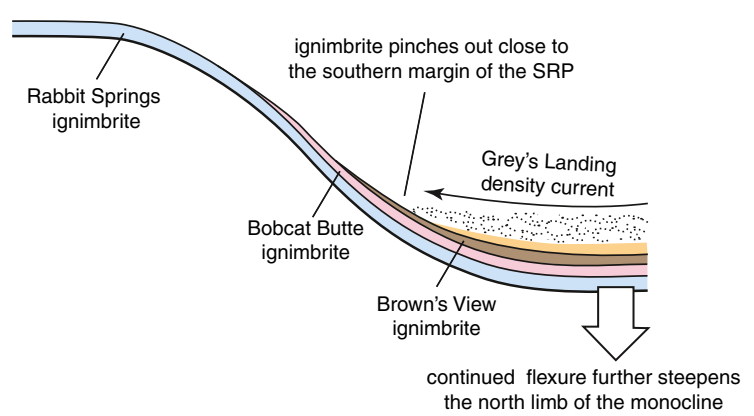

(e)

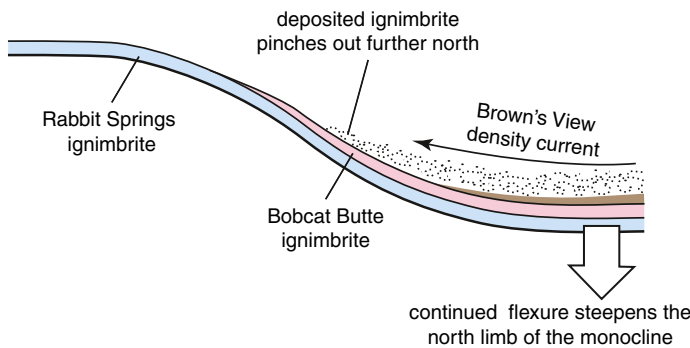

north limb of the monocline (c) 10 Ma - Brown's View eruption

$\mathbf{S}$

\section{BROWN'S BENCH MASSIF}

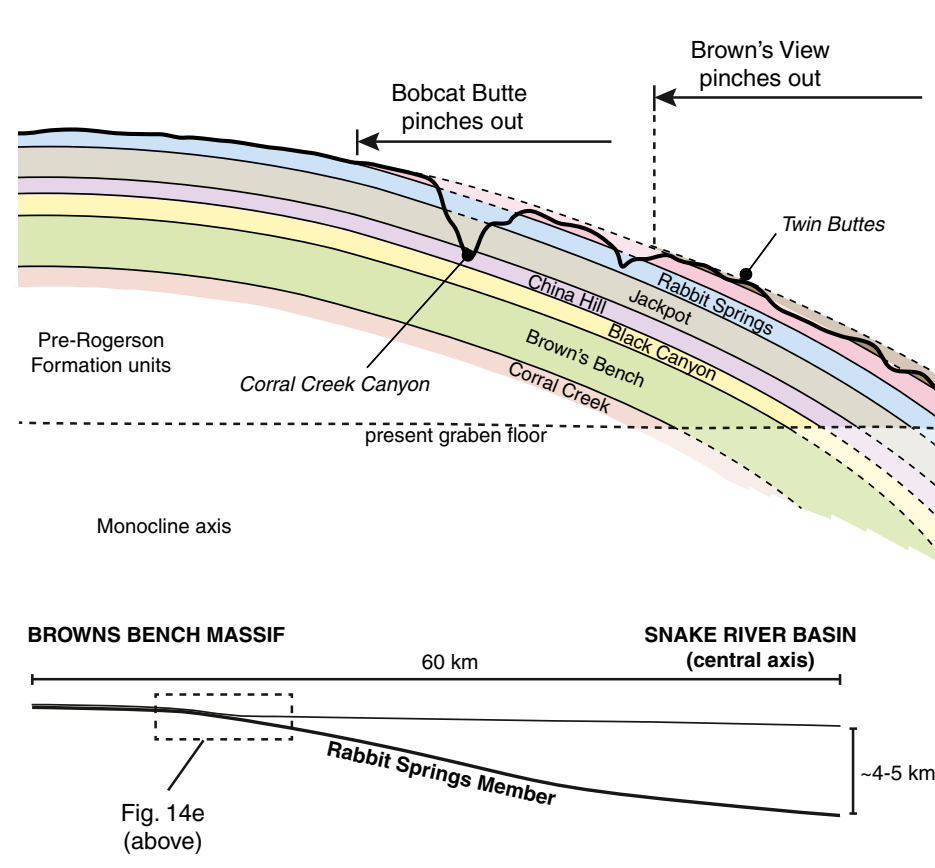

$\mathbf{N}$

SNAKE RIVER BASIN (southern margin)
Fig. 14 Reconstruction of the development of the Brown's Bench monocline (from 10.59 to $8.0 \mathrm{Ma}$; a-d) to account for the successive off-lapping of Rogerson Formation members (Note: diagrams not to scale). e Schematic diagram (not to scale) illustrating the northward thickness variations of all Rogerson Formation members and younger units confined within the Snake River Basin. Inset: inferred degree of subsidence along the Snake River Basin axis, demonstrated by projecting the northward dip of the Rabbit Springs Member beneath the plain 
than, for example, distance from source. It also confirms that Brown's Bench monocline development occurred contemporaneous with the development of Rogerson Graben. The Grey's Landing Member also thins markedly as it offlaps the north-dipping limb of the monocline (Fig. 14d), and it pinches out $\sim 3 \mathrm{~km}$ further north of Twin Buttes (Fig. 1). Marked southward thinning of the member is also documented at Monument Creek together with top-to-the north rheomorphic kinematic indicators (Andrews and Branney 2011). However, like the Brown's View Member, the Grey's Landing pyroclastic density current was able to flow $9 \mathrm{~km}$ further south down the subsiding Rogerson Graben, unconstrained by topography (the ignimbrite is $>65 \mathrm{~m}$ thick at Backwaters, Fig. 7). This indicates that the monocline continued to develop, generating northward sloping topography prior to the Grey's Landing eruption $(\sim 8.0 \mathrm{Ma})$, broadly at the time that the western faulted margin of the Rogerson Graben developed.

In summary, volcanological, kinematic, structural and geochronology data together indicate that subsidence of the Snake River Basin began prior to $10.34 \pm 0.09 \mathrm{Ma}$ in the Rogerson area, and that the Brown's Bench monocline developed, generating increasing northward topographic slopes prior to, and during, the Bobcat Butte, Brown's View and Grey's Landing eruptions $(\sim 10.3-8.0 \mathrm{Ma})$.

If the present-day, Yellowstone plateau is an appropriate analogue; the central Snake River Plain region may initially have been thermally elevated at the time of hotspot related explosive eruptions, before gradually subsiding due to loading by the developing crustal sill to form the present Snake River Basin. However, the evidence presented herein suggests that the central Snake River Plain was already actively subsiding during the large explosive rhyolitic eruptions, and that this subsidence coincided with east-west extension and development of the Rogerson Graben. Two additional lines of evidence for this notion are: (1) kinematic indicators and rheomorphic lineations indicate top to the north transport (Andrews and Branney 2011), (2) ignimbrites are subaerial on massifs both north and south of the central Snake River Plain, but with proximity to the plain they developed peperitic basal contacts (e.g. the Lincoln Reservoir and Wooden Shoe Members in the northern Cassia Hills to the East, Knott et al. 2016, and an ignimbrite that overlies fluvio-lacustrine sediments at Queens Crown on the north side of the Snake River Plain, Branney et al. 2008). This is consistent with the presence, during the ignimbrite eruptions, of surface water at the margins of an already subsiding central Snake River Basin.

\section{Conclusions}

1. Eleven rhyolitic members make up the substantially revised $\geq 420$-m-thick, mid-Miocene Rogerson formation in the central snake river plain of Idaho, and each represents a palaeosol-bound eruption unit. All are typical Snake River-type units (Branney et al. 2008) but can be distinguished using a combination of field, stratigraphic, geochemical, mineralogical, palaeomagnetic and radiometric data.

2. Two widespread ignimbrite sheets have been discovered by new regional correlations: the $100 \mathrm{~km}^{3}$ Brown's View Member that covers $\geq 3300 \mathrm{~km}^{2}$ and the $\sim 130 \mathrm{~km}^{3}$ Wooden Shoe Member that covers $\geq 4400 \mathrm{~km}^{2}$ and extends into northern Nevada. Moreover, we anticipate that the distinguishing features reported in this paper for the individual members of the Rogerson Formation should contribute to more extensive regional correlations of other eruption units.

3. Eleven large explosive rhyolitic eruptions occurred during a period of 3.9 million years, with an average explosive eruption frequency of one eruption per $354 \mathrm{ky}$, more than twice the frequency of the more recent eruptions at Yellowstone.

4. The ignimbrite succession records two systematic temporal trends in major element, trace element, and mineral chemistry: (1) a period of increasing rhyolite maturity (e.g. increasing $\mathrm{SiO}_{2}$, and decreasing $\mathrm{TiO}_{2}$ between $\sim 11.9$ and $11.3 \mathrm{Ma}$ ) that may record progressive fractional crystallisation, followed by (2) a period of decreasing maturity (between $\sim 11.0$ and $10.0 \mathrm{Ma}$ ) that may reflect the partial melting and evolution of a mid-crustal source region.

5. The central Snake River Plain subsided to form a regional basin during the explosive rhyolitic volcanism, as recorded by ignimbrite thickness changes, offlap relations and rheomorphic kinematic indicators on the north limb of a regional W to WSW-trending basin-margin monocline. In the Rogerson area, this initiated after $10.59 \mathrm{Ma}$ and continued to develop until $\sim 8 \mathrm{Ma}$. This subsidence was caused by voluminous magmatism and began earlier than further east in the Cassia Hills (Knott et al. 2016). The syn-volcanic subsidence was in marked contrast to the presently elevated Yellowstone plateau.

6. East-west basin-and-range extension contemporaneous with the rhyolitic volcanism and magmatic subsidence produced the N-S trending Rogerson Graben and related Shoshone Hills structures. Initial regional westward tilting (uplift of the early Shoshone Hills $\geq 10.34 \mathrm{Ma}$ ) was followed by initiation of the Shoshone Hills Fault system with development of an eastward-sloping half-graben $(\sim 10.3-$ 10.1 Ma). The dominant Brown's Bench Fault then initiated ( 10.1-8.0 Ma) with a major reversal in the graben asymmetry. This fault remained intermittently active at least until the Pliocene. At approximately the same time, the opening west Snake River rift (to the NW) propagated as far south as Salmon Reservoir, with eruption of ferrobasalts from Salmon Butte shield volcano. 
Acknowledgments This work was funded by NERC NE/G005672/1 to the University of Leicester. We greatly appreciate the encouragement from many experts including Bill Leeman, John Wolff, Marty Godchaux, Ben Ellis and Tiffany Barry. L. McDonald and F. Wadsworth assisted in the field, and M. Heinrich and A. Batz assisted in the laboratory. We also thank David Brown and an anonymous reviewer for their comments, which have greatly improved the final version.

Open Access This article is distributed under the terms of the Creative Commons Attribution 4.0 International License (http:// creativecommons.org/licenses/by/4.0/), which permits unrestricted use, distribution, and reproduction in any medium, provided you give appropriate credit to the original author(s) and the source, provide a link to the Creative Commons license, and indicate if changes were made.

\section{References}

Andersen DJ, Lindsley DH, Davidson PM (1993) QUILF: a Pascal program to assess equilibria among $\mathrm{Fe}-\mathrm{Mg}-\mathrm{Mn}-\mathrm{Ti}$ oxides, pyroxenes, olivine, and quartz. Comp \& Geosci 19(9):1333-1350. doi:10.1016/ 0098-3004(93)90033-2

Andrews GDM, Branney MJ (2005) Folds, fabrics, and kinematic criteria in rheomorphic ignimbrites of the Snake River Plain, Idaho: insights into emplacement and flow. Geol Soc Am Field Guide 6:311-328

Andrews GDM, Branney MJ (2011) Emplacement and rheomorphic deformation of a large rhyolitic ignimbrite. Grey's Landing, southern Idaho. Geol Soc Am Bull 123:725-743. doi:10.1130/B30167.1

Andrews GDM, Branney MJ, Bonnichsen B, McCurry M (2008) Rhyolitic ignimbrites in the Rogerson Graben, southern Snake River Plain volcanic province: volcanic stratigraphy, eruption history and basin evolution. Bull Volcanol 70:269-291

Armstrong RL, Leeman WP, Malde HE (1975) K-Ar dating of quaternary and neogene volcanic rocks of the Snake River Plain, Idaho. Am J Science 273:225-251

Beranek LP, Link PK, Fanning CM (2006) Miocene to Holocene landscape evolution of the western Snake River Plain region, Idaho: Using the SHRIMP detrital zircon provenance record to track eastward migration of the Yellowstone hotspot. Geol Soc Am Bull 118: 1027-1050. doi:10.1130/B25896.1

Bonnichsen B, Citron GP (1982) The Cougar Point Tuff, southwestern Idaho and vicinity, In: Bonnichsen, B., and Breckenridge, R.M. (eds) Cenozoic Geology of Idaho. Idaho Bur Min Geol Bull 26: 255-281

Bonnichsen B, Godchaux MM (2002) Late Miocene, Pliocene, and Pleistocene geology of southwestern Idaho with emphasis on basalts in the Bruneau-Jarbidge, Twin Falls, and western Snake River Plain regions, In: Bonnichsen, B. et al. (eds) Tectonic and magmatic evolution of the Snake River Plain volcanic province. Idaho Geol Sur Bull 30:233-312

Bonnichsen, B., and Kauffman, D.F. (1987) Physical features of rhyolite lava flows in the Snake River Plain volcanic province, southwestern Idaho, In: Fink, J.H. (eds) The Emplacement of Silicic Domes and Lava Flows: Geol Soc Am Special Paper 212:119-145

Bonnichsen B, Leeman W, Honjo N, McIntosh W, Godchaux M (2008) Miocene silicic volcanism in southwestern Idaho: geochronology, geochemistry, and evolution of the central Snake River Plain. Bull Volcanol 70:315-342. doi:10.1086/516024

Boroughs S, Wolff JA, Bonnichsen B, Ellis BS, Larson P (2012) Evaluating models of the origin of Miocene low $-\delta^{18} \mathrm{O}$ rhyolites of the Yellowstone/Columbia River large igneous province. Earth Plan Sci Lett 313:45-55. doi:10.1016/j.epsl.2011.10.039

Branney MJ (1991) Eruption and depositional facies of the Whorneyside Formation, English Lake District: an exceptionally large-magnitude phreatoplinian eruption. Geol Soc Amer Bull 103:886-897

Branney MJ, Kokelaar BP (1992) A reappraisal of ignimbrite emplacement: particulate to non-particulate flow transitions during progressive aggradation of high-grade ignimbrite. Bull Volcanol 54:504 520

Branney MJ, Kokelaar BP (2002) Pyroclastic density currents and the sedimentation of ignimbrites. Mem, Geol Soc Lond 27:1-143

Branney MJ, Kokelaar BP, McConnell BJ (1992) The Bad Step Tuff a lava-like rheomorphic ignimbrite in a calc-alkaline piecemeal caldera, English Lake District. Bull Volcanol 54:187-199. doi:10.1007/ BF00278388

Branney MJ, Barry TL, Godchaux MM (2004) Sheathfolds in rheomorphic ignimbrites. Bull Volcanol 66:485-491. doi:10.1007/ s00445-003-0332-8

Branney M, Bonnichsen B, Andrews G, Ellis B, Barry T, McCurry M (2008) Snake River (SR)-type' volcanism at the Yellowstone hotspot track: distinctive products from unusual, high-temperature silicic super-eruptions. Bull Volcanol 70:293-314. doi:10.1007/ s00445-007-0140-7

Breitkreuz C (2013) Spherulites and lithophysae - 200 years of investigation on high-temperature crystallization dominas in silica-rich volcanic rocks. Bull Volcanol 75:705-719. doi:10.1007/s00445-0130705-6

Brown R, Branney MJ (2013) Internal flow variations and diachronous sedimentation within extensive, sustained, density-stratified pyroclastic density currents flowing down gentle slopes, as revealed by the internal variations of ignimbrites on Tenerife. Bull Volcanol 75: 727. doi:10.1007/s00445-013-0727-0

Brown RJ, Branney MJ, Maher C, Dávila-Harris P (2010) Origin of accretionary lapilli within ground-hugging density currents: evidence from pyroclastic couplets. Geol Soc Am Bull 122:305-320. doi:10.1130/B26449.1

Carey SN, Sigurdsson H, Sparks RSJ (1988) Experimental studies of particle-laden plumes. J Geophys Res 93:15314-15328

Cathey HE, Nash BP (2004) The Cougar Point Tuff: implications for thermochemical zonation and longevity of high-temperature, largevolume silicic magmas of the Miocene Yellowstone Hotspot. J Petrol 45:27-58

Christiansen, R.L. (2001) The Quaternary and Pliocene Yellowstone Plateau Volcanic Field of Wyoming, Idaho, and Montana. US Geol Surv Professional Paper 729-G:146 pp

Christiansen RL, Foulger GR, Evans JR (2002) Upper-mantle origin of the Yellowstone hotspot. Geol Soc Am Bull 114:1245-1256

Coble MA, Mahood GA (2012) Initial impingement of the Yellowstone plume located by widespread silicic volcanism contemporaneous with Columbia River flood basalts. Geology 40:655-658

Colón DP, Binderman IN, Ellis BS, Schmitt AK, Fisher CM (2015) Hydrothermal alteration and melting of the crust during the Columbia River Basalt-Snake River Plain transition and the origin of low- $\delta^{18} \mathrm{O}$ rhyolites of the central Snake River Plain. Lithos 244: 310-323

Ellis B, Branney MJ (2010) Silicic phreatomagmatism in the Snake River Plain: the Deadeye Member. Bull Volcanol 72:1247-1257. doi:10. 1007/s00445-010-0400-9

Ellis BS, Wolff JL (2012) Complex storage of rhyolite in the central Snake River Plain. J Volcanol Geotherm Res 211:1-11. doi:10. 1016/j.jvolgeores.2011.10.002

Ellis B, Barry T, Branney MJ, Wolff JA, Bindeman I, Wilson R, Bonnichsen B (2010) Petrologic constraints on the development of a large-volume, high temperature, silicic magma system: The Twin Falls eruptive centre, central Snake River Plain. Lithos 120:475489. doi:10.1016/j.lithos.2010.09.008 
Ellis B, Branney MJ, Barry TL, Barfod D, Bindeman I, Wolff JA, Bonnichsen B (2012) Geochemical correlation of three largevolume ignimbrites from the Yellowstone hotspot track, Idaho, USA. Bull Volcanol 74:261-277. doi:10.1007/s00445-011-0510-Z

Ellis BS, Wolff JA, Boroughs S, Mark DF, Starkel WA, Bonnichsen B (2013) Rhyolitic volcanism of the central Snake River Plain: a review. Bull Volcanol 75:745-764. doi:10.1007/s00445-013-0745-y

Ellis BS, Bachmann O, Wolff JA (2014) Cumulate fragments in silicic ignimbrites: the case of the Snake River Plain. Geology 42(5):431434. doi: $10.1130 / \mathrm{G} 35399.1$

Ellis BS, Cordonnier B, Rowe MC, Szymanowski D, Bachman O, Andrews GDM (2015) Groundmass crystallisation and cooling rates of lava-like ignimbrites: the Grey's Landing Ignimbrite, southern Idaho, USA. Bull Volcanol 77:87. doi: 10.1007/s00445-015-0972-5

Finn DR, Coe RS, Kelly H, Branney MJ, Knott TR, Reichow MK (2015) Magnetic anisotropy in rhyolitic ignimbrite, Snake River Plain: Implications for using remanent magnetism of volcanic rocks for correlation, paleomagnetic studies, and geological reconstructions. J Geophys Res: Solid Earth 120:4014-4033. doi:10.1002/ 2014JB011868

Fisher RV, Schmincke H-U (1984) Pyroclastic rocks. Springer, Berlin, $472 \mathrm{pp}$

Henry CD, Wolff JA (1992) Distinguishing strongly rheomorphic tuffs from extensive silicic lavas. Bull Volcanol 54:171-186

Hildreth W (1979) The Bishop Tuff: evidence for the origin of compositional zonation in silicic magma chambers. Geol Soc Am Special Paper 180:43-75

James DE, Fouch MJ, Carlson RW, Roth JB (2011) Slab fragmentation, edge flow and the origin of the Yellowstone hotspot track. Earth Plan Sci Lett 311:124-135

Knott, T.R., Reichow, M.K., Branney, M.J., Finn, D.R., Coe, R.S., Storey, M., Barfod, D., McCurry, M. (2016) The Cassia Formation, Idaho, USA: Mid-Miocene record of large-scale Snake River-type explosive volcanism and associated subsidence on the Yellowstone hotspot track. Geol Soc Am Bull (in press). doi:10.1130/B31324.1

Lavallée Y, Wadsworth FB, Vasseur J, Rssell JK, Andrews GDMA, Hess K-U, von Aulock FW, Kendrick JE, Tuffen H, Biggin AJ, Dingwell DB (2015) Eruption and emplacement timescales of ignimbrite super-eruptions from thermo-kinetics of glass shards. Front Earth Sci 3:2. doi:10.3389/feart.2015.00002

Leeman W, Annen C, Dufek J (2008) Snake River Plain-Yellowstone silicic volcanism: implications for magma genesis and magma fluxes, In: Annen, C. and Zellmer, G. F. (eds) Dynamics of Crustal Magma Transfer, Storage and Differentiation. Geol Soc Lond Special Publ 304:235-259

Malde HE, Powers HA (1962) Upper Cenozoic stratigraphy of the western Snake River Plain, Idaho. Geol Soc Am Bull 73(10):1197-1210. doi:10.1130/0016-7606(1962)73[1197:UCSOWS]2.0.CO;2

McCurry M, Rodgers DW (2009) Mass transfer along the Yellowstone hotspot track I: petrologic constraints on the volume of mantlederived magma. J Volcanol Geotherm Res 188:86-98. doi:10. 1016/j.jvolgeores.2009.04.001

McQuarrie N, Rodgers DW (1998) Subsidence of a volcanic basin by flexure and lower crustal flow: the eastern Snake River Plain, Idaho. Tectonics 17(2):203-220. doi:10.1029/97TC03762
Miller EI, Dumitru TA, Brown RW, Gans PB (1999) Rapid Miocene slip on the Snake Range-Deep Creek Range Fault system, east-central Nevada. Geol Soc Ame Bull 111:886-905

Nash BP, Perkins ME, Christensen JN, Lee D-C, Halliday AN (2006) The Yellowstone hotspot in space and time: $\mathrm{Nd}$ and $\mathrm{Hf}$ isotopes in silicic magmas. Earth Plan Sci Lett 247:143-156

Othberg KL, Kauffman JD, Gillerman DL, Garwood DL (2012) Geological map of the Twin Falls $30 \times 60$ minute quadrangle. Idaho, Idaho Geol Surv, scale 1:100,000

Peng X, Humphreys ED (1998) Crustal velocity structure across the eastern Snake River Plain and the Yellowstone swell. J Geophys Res 103:7171-7186. doi:10.1029/97JB03615

Perkins ME (1998) Sequence, age, and source of silicic fallout tuffs in middle to late Miocene basins of the northern Basin and Range province. Geol Soc Am Bull 110(3):344-360

Pierce KL, Morgan LA (1992) The track of the Yellowstone hot spot: volcanism, faulting, and uplift. In: Link, P.K., Kuntz, M.A., and Platt, L.B. (eds) Regional Geology of Eastern Idaho and Western Wyoming. Geol Soc Am Mem 179:1-53

Rivera TA, Storey M, Zeeden C, Hilgen FJ, Kuiper K (2011) A refined astronomically calibrated ${ }^{40} \mathrm{Ar} /{ }^{39} \mathrm{Ar}$ age for Fish Canyon sanidine. Earth Plan Sci Lett 311:420-426

Robert G, Andrews GDM, Ye J, Whittington AG (2013) Rheological controls on the emplacement of extremely high-grade ignimbrites. Geology 41:1031-1034. doi:10.1130/G34519.1

Rodgers DW, Ore HT, Bobo RT, McQuarrie N, Zentner N (2002) Extension and subsidence of the eastern Snake River Plain, Idaho, In: Bonnichsen, B., White, C.M., McCurry M., (eds) Tectonic and Magmatic Evolution of the Snake River Volcanic Province. Idaho Geol Surv Bull 30:121-155

Self S, Blake S (2008) Consequences of Explosive super eruptions: Elements 4:41-46

Shervais JW, Vetter SK, Hanan BB (2006) Layered mafic sill complex beneath the eastern Snake River Plain: evidence from cyclic geochemical variations in basalt. Geology 34:365-368. doi:10.1130/ G22226.1

Shervais JW et al (2013) First Results from HOTSPOT: The Snake River Plain Scientific Drilling Project, Idaho, U.S.A. Scientific Drilling 15:36-45

Smith, R.L. (1960) Zones and Zonal Variations in Ash Flows. US Geol Surv Professional Paper 354-F:159 pp

Sparlin MA, Braile LW, Smith RB (1982) Crustal structure of the eastern Snake River Plain determined from ray trace modelling of seismic refraction data. J Geophys Res: Solid Earth 87:2619-2633. doi:10. 1029/JB087iB04p02619

Suzuki-Kamata K, Ui T (1988) Depositional ramps: asymmetrical distribution structure in the Ata pyroclastic flow deposit, Japan. Bull Volcanol 50:26-34

Wilson CJN, Hildreth W (2003) Assembling and ignimbrite: mechanical and thermal building blocks in the Bishop Tuff, California. J Geophys Res 111:653-670

Wright KE, McCurry M, Hughes SS (2002) Petrology and geochemistry of the Miocene tuff of McMullen Creek, central Snake River Plain. In: Bonnichsen, B., McCurry, M., White, C.M., (eds) Tectonic and magmatic evolution of the Snake River Plain volcanic province. Idaho Geol Surv Bull 30:177-194 